\title{
ARCHEOLOGICKÝ VÝZKUM RÝŽOVIŠTĚ V NOVÉ VÉSCE (MÍSTNÍ ČÁST OBCE STARÉ MĚSTO, OKRES BRUNTÁL)
}

\author{
MICHAL ZEZULA - JANA BRHELOVÁ - PETR KOČÁR - LIBOR PETR - JOSEF VEČĚ̌A
}

\begin{abstract}
Abstrakt: Archeologický výzkum v západni části katastru obce Nová Véska dokumentoval rýžoviště situované na Černém potoce, ve kterém byly těženy aluviálni sedimenty s obsahem zlata zachycené ve zvětralém skalním podloží. Postup těžby umožnila rekonstruovat analýza terénních tvarů zobrazených v digitálním modelu reliéfu. Rozbor materiálu deponovaného v rámci archeologicky zkoumaných hald a vrstev vyplňujicich terénni deprese ukazuje způsob zpracování rýžovaných sedimentů a mechanismus vzniku zdejšiho montánního reliéfu. Environmentálni výzkum, jehož nejdi̊ležitějši část představovala palynologie vzorků odebraných $z$ archeologických sond a jednoho vrtaného profilu, přinesl informace o náhlém vstupu montánnich aktivit do člověkem doposud neovlivněné zalesněné krajiny, změnách vegetace následujicich po ukončeni těžby a nástupu agrárnich aktivit. Na základě radiokarbonové datace můžeme rýžovnickou činnost a sledovaný vývoj vegetace v jejím okoli provázat s historickými zprávami o osídlovacím procesu Bruntálska v prủběhu 13. až 14. století.
\end{abstract}

Klíčová slova: Bruntálsko - rýžování zlata - vrcholně středověké osidlení - environmentální analýza - pylový profil.

\section{Archaeological research into a panning site in Nová Véska (part of Staré Město, Bruntál district)}

\begin{abstract}
Archaeological research in the western section of the Nová Véska village cadastre documented a panning site located on the Černý potok stream where alluvial sediments containing gold found in the weathered bedrock were mined. The mining process was reconstructed by the analysis of the land formations shown in a digital model of the landscape relief. The analysis of the material yielded by the archaeologically investigated heaps and layers filling the terrain depressions illustrates the manner of the processing of the mined sediments and the mechanism of the formation of the local mining relief. Environmental research, the most important part of which was the palynology of samples taken from the archaeological probes and one drilled profile, provided information about the sudden onset of mining activities in a forested landscape previously unaffected by man, the changes in vegetation following the end of mining and the beginning of farming activities. On the basis of radiocarbon dating, the panning activity and the observed development of vegetation in its surroundings can be linked to historical accounts of the settlement process in the Bruntál region in the course of the 13th and 14th centuries.
\end{abstract}

Key words: Bruntál region - panning - settlement from the high Middle Ages - environmental analysis - pollen profile.

\section{1 Úvod}

Počátky středověkého osídlení Bruntálska jsou svázány se zájmem přemyslovských panovníků, českého krále Přemysla Otakara I. a jeho bratra moravského markraběte Vladislava Jindřicha, na exploataci zlata $\mathrm{v}$ podhůř́i Hrubého Jeseníku. V souvislosti s tím zde byl před rokem 1213 lokován Bruntál jako nejstarší institucionální město v českých zemích, jak vyplývá z údajů uničovského privilegia z roku 1223 (CDB II, 237-239 č. 246, k tomu srov. Wihoda 2019, 147-151; Kejř 1998, 150; Žemlička 2002, 274; Klápště 2005, 365-366; Prix 2017) a ze skutečnosti, že se v průběhu 13. století jednalo o regionální centrum magdeburského městského práva na severní Moravě a na Opavsku (Bakala 2002, 269; Wihoda 2019, 161). Předpokládá se, že prvotní Bruntál zřejmě ještě neměl pevnou urbanistickou strukturu a magdeburské městské právo zajištovalo sít hornických osad, jejichž církevním centrem byl areál dnešního kostela Neposkvrněného Početí Panny Marie ve Starém Městě (Wihoda 2019, 150; Prix 2017, 133-139). Je zřejmé, že osídlovací proces byl v prvních desetiletích 13. století na Bruntálsku velmi dynamický a postup těžby zlatonosných sedimentů byl př́íčinou rychlých strukturálních změn. Prospektoři a těžaři postupovali proti proudu řeky Opavy, Moravice a Černého potoka až k primárním ložiskům v oblasti Hláska-Vysoká 
a spolu s nimi se přesouvalo jejich zázemí (Večeřa 2017; Prix 2017; k tomu též Derner et al. 2019, 938-940). Rýžování zlata z fluviálních sedimentů bylo velmi efektivní, nicméně během relativně krátké doby došlo $\mathrm{k}$ vytěžení těchto ložisek a návazná důlní těžba, s výjimkou velkých povrchových dobývek, již zdaleka nebyla tak rentabilní. Je pravděpodobné, že ukončení první etapy těžby, spočívající v těžbě snadno dostupných ložisek zlata, představovalo impulz pro agrární transformaci osídlení Bruntálska a s ní spojený vznik normativně vyměřených vesnic a tržního centra v místě dnešního historického jádra Bruntálu.

Archeologické doklady počáteční fáze středověkého osídlení Bruntálska z první poloviny 13. století jsou doposud jen málo početné, většina z nich pochází z areálu kostela Neposkvrněného Početí P. Marie ve Starém Městě (přehledně Zezula 2017). Mimořádný význam má v této souvislosti archeologický odkryv exploatačního a zpracovatelského areálu v Suché Rudné (Večeřa-Malík-Zezula 2014; Malík-Večeřa-Zezula 2017), jehož činnost se na základě četných dendrochronologických dat řadí do doby kolem přelomu 20. a 30. let 13. století. Další poznatky pocházejí z uničovského horního obvodu situovaného jižně od Bruntálska, ke kterému náležela archeologicky odkrytá hornická osada předcházející lokaci města Rýmařova (naposledy GošKarel 2003, zde odkazy k dalším publikacím výzkumu této lokality). Archeologický výzkum montánních areálů v prostoru moravsko-slezského pomezí ale není zdaleka tak rozvinutý jako v případě jiných hornických revírů v českých zemích (srov. např. Derner et al. 2019) nebo v sousedním Dolním Slezsku (Stolarczyk 2012; 2013).

\section{Montánní činnost ve 13. století na Bruntálsku a její relikty}

Na Bruntálsku a v jeho sousedství (obr. 1) se setkáváme s výskytem stříbrných rud jihovýchodně od města v okolí Horního Benešova, dále s ložisky železných rud v pruhu mezi Horními Životicemi - Leskovcem a Moravským Berounem a směrem na západ v okolí Malé Morávky. Nejdůležitější surovinou, která představovala impulz k osídlení zdejšího kraje v první polovině 13. století, bylo však zlato. Množství pozůstatků po dolování zlatých rud se nachází severozápadně od Bruntálu. Jedná se hlavně o zbytky po rýžování pokrývající nivu a přilehlé břehy řeky Opavy od Vrbna p. Pradědem po Nové Heřminovy. Menší rýžoviště jsou na Uhlířském potoce jako pravobřežním přítoku řeky Opavy nebo v povodí Černého potoka, který se jižně od Bruntálu vlévá do řeky Moravice.

Snadno získatelné zlato z říčních rozsypů přivedlo prospektory a posléze i těžaře do prostoru výskytu primárních rud v okolí Suché Rudné a vrchů Hlásky a Vysoké. Zvláště v Suché Rudné se zachovaly mohutné povrchové dobývky, z nichž největší Měkká žíla má délku $500 \mathrm{~m}$, šířku $50 \mathrm{~m}$ a hloubku okolo $10 \mathrm{~m}$. Je pravděpodobné, že jejich vznik časově souvisí s počátky osídlovacího procesu Bruntálska v první polovině 13. století, podobně jako archeologicky dokumentovaný těžební a zpracovatelský areál z tohoto období mezi Měkkou žílou a jižněji položenými dobývkami Podmáslí (Večeřa-Malík-Zezula 2014; Malík-Večeřa-Zezula 2017).

Zcela mimořádné jsou pozůstatky hornické činnosti severně od Suché Rudné na kótách Hláska a Vysoká. Mimořádnost nespočívá ani tak v délce dokumentovaných důlních tahů $(4,5 \mathrm{~km})$, ale spíše v jejich zachovalosti. Jedná se totiž většinou o průzkumná důlní díla spadající svým charakterem do středověku, jen minimálně narušená mladší těžební činností (Večeřa 2007). Podle charakteru důlních děl se jedná o nehluboká díla, s odhadovanou hloubkou do $10 \mathrm{~m}$. To svědčí o tom, že zdejší rudy byly chudé a jejich dobývání ve větší hloubce se již nevyplácelo. Nepřímým potvrzením tohoto předpokladu je i absence štol a minimální porušení mladšími díly.

\section{Cíle výzkumu}

Př́ležitost cíleně získat nové archeologické prameny představují interdisciplinárně koncipované terénní odkryvy a dokumentace vybraných nalezišt' v jesenické oblasti v rámci projektů podpořených programem Ministerstva kultury ČR NAKI II Archeologie z nebe a Pamět' moravských 


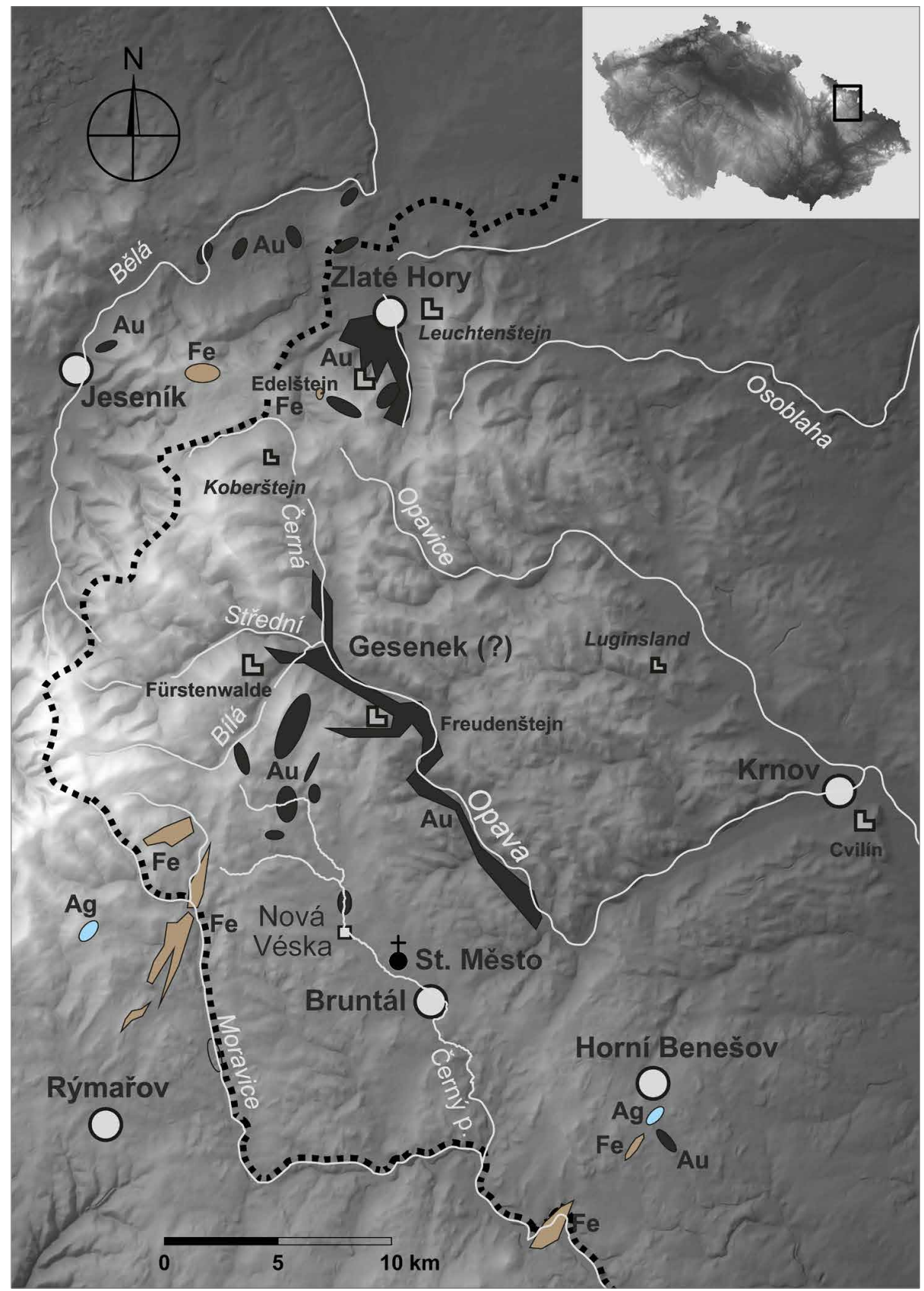

Obr. 1. Bruntálsko a západní část středověkého Opavska (hranice vyznačena tečkovaně) s hlavními doly, hrady a městy a lokalizací Nové Vésky. Podkladová data DMR European Digital Elevation Model, version 1.1, Copernicus Land; vodní toky podle Digitální báze vodohospodářských dat (DIBAVOD), Výzkumný ústav vodohospodářský T. G. Masaryka, v. v. i. Autoři J. Večeřa a M. Zezula, technické zpracování R. Kadlubiec.

Abb. 1. Region Bruntál und westlicher Teil der mittelalterlichen Region Opava (Grenze durch punktierte Linie gekennzeichnet) mit Hauptgruben, Burgen und Städten sowie der Lokalisierung von Nová Véska. Datenvorlage DMR European Digital Elevation Model, Version 1.1, Copernicus Land; Wasserläufe gemäß Digitaler Datenbank für wasserwirtschaftliche Daten (DIBAVOD), T. G. Masaryk-Forschungsinstitut für Wasserwirtschaft. Autoren J. Večeřa und M. Zezula, technische Bearbeitung R. Kadlubiec. 
a slezských Sudet v ohrožení. Prvním publikačním výstupem těchto projektů je předkládaný příspěvek věnovaný rýžovišti v západní části katastru obce Nová Véska (obr. 2), zmíněné písemnými prameny poprvé k roku 1405 (CDS II, 48-50 č. 49; Prix 2017). Založení Nové Vésky, jež předpokládáme již kolem poloviny 13. století, je výsledkem kolonizační akce organizované patrně z podnětu zeměpána a za spoluúčasti starobruntálského rychtáře či někoho z bruntálských měštanů, pro což hovoří jak úzká vazba na staroměstský katastr, tak i příslušnost ke zdejší faře spolu s okolností, že ves spadala v 16. století pod jurisdikci bruntálské městské rady (Prix 2017). V intravilánu Starého Města i na něj navazující Nové Vésky jsou terénní relikty těžby zlata takřka bezezbytku aplanovány, $\mathrm{v}$ západní části zalesněného úseku novovéseckého katastru se stopy rýžovnické činnosti velmi dobře dochovaly a $\mathrm{v}$ roce 2019 byly částečně odhaleny $\mathrm{v}$ důsledku kalamitní kůrovcové těžby, takže byla možná jejich dokumentace laserovým leteckým i pozemním skenováním, doplněná o plošně omezený terénní odkryv formou dvou ručně kopaných sond, jehož součástí byl odběr vzorků pro prrírodovědné analýzy. Cílem archeologického výzkumu bylo získat relevantní informace o dataci a pozici tohoto těžebního areálu v rámci vrcholně středověkého osídlovacího procesu Bruntálska a zároveň s využitím geologických metod postihnout genezi a vývoj zde dochovaných montánních reliktů.

Cílem archeobotanických analýz bylo rekonstruovat vegetaci a prostředí, do kterého přišli první kolonisté, a zjistit, jaké složení měl tehdejší les a zda montánní aktivita měla i bezprostřední zemědělské zázemí. Profil nivních sedimentů dále ukazuje využívání krajiny po ukončení těžby a její zemědělské využívání. Analyzované lokality přímo souvisí s těžbou zlata a jejich paleoekologická evidence doplňuje dosavadní poznatky o holocenním vývoji vegetace a krajiny v Jeseníkách z řady pylových profilů z přirozených rašeliništ', prrípadně potočních niv (Dudová et al. 2013; 2014; 2018).

\section{Metody výzkumu}

V roce 2019 byla část plochy rýžoviště severně od silnice zaměřena metodou pozemního laserového skenování laserovým skenerem FARO Focus X330 (Tejkal 2019). V návaznosti na využití uvedené dokumentační metody byla $\mathrm{v}$ prostoru rýžoviště za pomoci pedologické sondy vytipována místa $\mathrm{s}$ výskytem zvodnělých sedimentů. $\mathrm{V}$ jejich rámci pak byly $\mathrm{v}$ části rýžoviště situované mezi Černým potokem a silnicí otevřeny dvě sondy (S18 a S19) s cílem získat detailní informace o charakteru jeho reliéfu a také získat vzorky pro archeobotanické analýzy. Z většiny dokumentovaných vrstev se podařilo odebrat vzorky, ze kterých byla v laboratorních podmínkách separována soustavou sít hrubá frakce v několika velikostních kategoriích. Analýza jejich složení pomohla vyhodnotit jednotlivé uloženiny z hlediska jejich geneze a lépe tak pochopit mechanismus vzniku zdejšího montánního reliéfu.

Následně v letech 2020 a 2021 provedl CzechGlobe, Ústav výzkumu globální změny AV ČR, laserové letecké skenování terénu rýžoviště (Hanuš-Fajmon 2021). Pořízená data byla dále zpracována v kompozitní vizualizaci, složené ze tř́i vrstev dohromady kombinovaných pomocí průhlednosti. Vizualizace je tvořena spodní vrstvou stínovaného digitálního modelu reliéfu (DMR, hillshade), která slouží pro základní představu o celkové topografii terénu řešené oblasti, střední vrstvou rastru SVF (Sky view factor), usnadňující detekci zahloubených objektů a jejich interpretaci $\mathrm{v}$ řezu a svrchní vrstvou zjednodušeného lokálního modelu reliéfu (LRM, Local relief model), zvýrazňujícího zejména vystupující hrany. Celá vizualizace byla zacílena na zvýraznění větších i drobných či značně aplanovaných terénních nerovností, což umožnilo mnohem podrobnější popis rýžoviště a analýzu v něm zastoupených terénních tvarů. ${ }^{1}$

Součástí archeologického výzkumu rýžoviště v Nové Vésce byl i archeobotanický výzkum zahrnující palynologii a analýzu rostlinných (makro)zbytků (semen a plodů rostlin a zlomků

1 Za zpracování vizualizací dat LLS děkujeme kolegovi Mgr. O. Malinovi, Ph.D., z Národního památkového ústavu, územního odborného pracoviště v Lokti. 


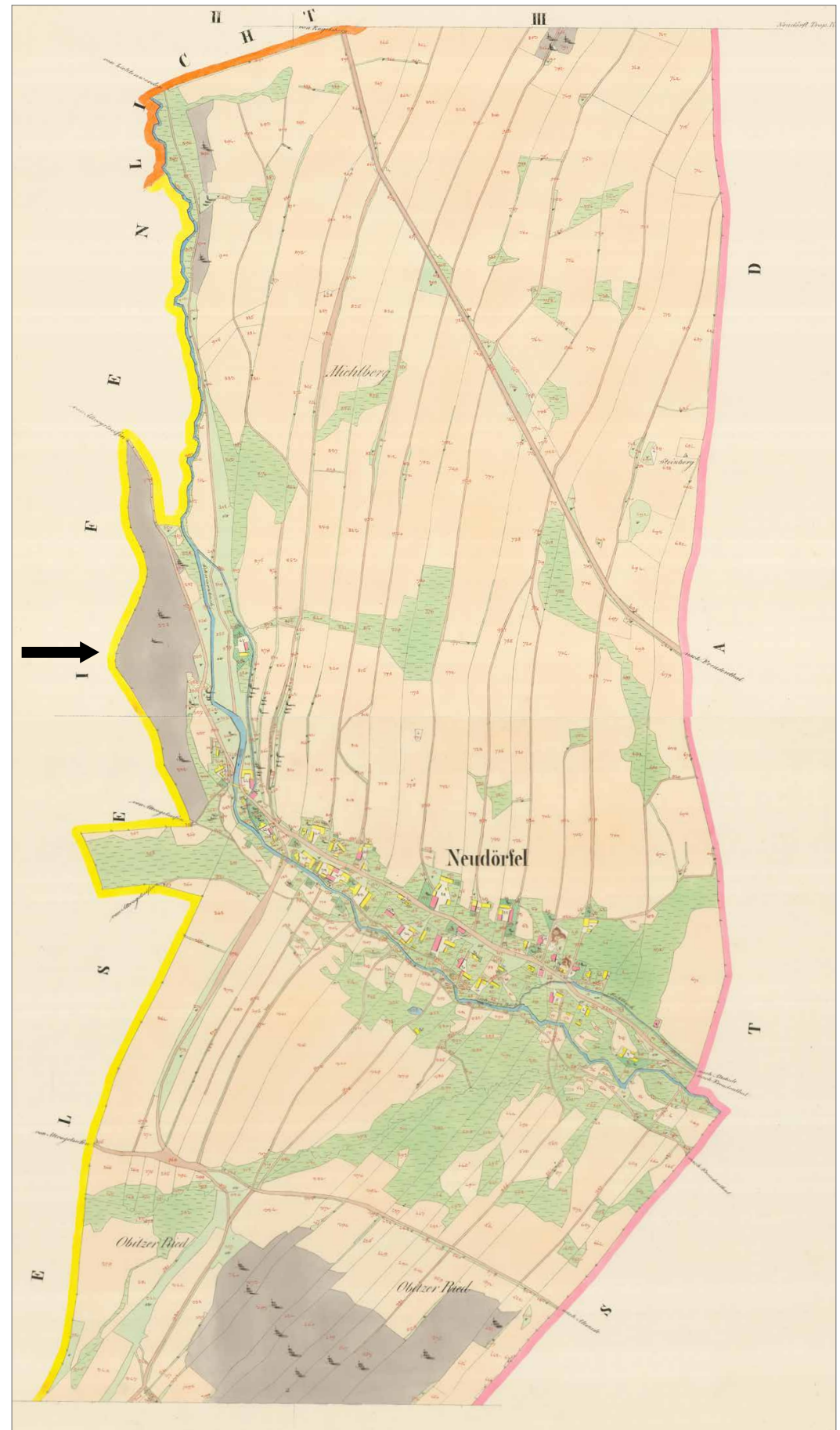

Obr. 2. Nová Véska na císařském povinném otisku map stabilního katastru z roku 1836. Rýžoviště v západní části katastru je označeno šipkou. Zdroj Ústřední archiv zeměměřictví a katastru ČÚZK, upravil M. Zezula.

Abb. 2. Nová Véska auf einem kaiserlichen Pflichtabdruck des stabilen Katasters von 1836. Goldseife im Westteil des Katasters mit Pfeil gekennzeichnet. Quelle Zentralarchiv für Landesvermessung und Kataster, Bearbeitung M. Zezula. 
uhlíků či dřev) získaných vzorkováním studovaných situací v profilech archeologických sond a vrtaný profil v nivě Černého potoka v sousedním katastru Staré Rudné. Vzorek sedimentu určený k získání uhlíků byl proplaven přes soustavu sít o nejmenším průměru ok $1 \mathrm{~mm}$. Uhlíky byly vybrány pod stereoskopickým mikroskopem a analyzovány na čerstvých lomech pomocí episkopického mikroskopu (zvětšení $50 \times 100 \times$ a $200 \times$ ). Zaznamenány byly počty zlomků ve zpracovávaných vzorcích. Pro determinaci byla použita literatura $\mathrm{k}$ určování dřeva a uhlíků (Schweingruber 1978) a sbírka dřeva středoevropských dřevin.

Vzorky pro pylovou analýzu byly odebrány přímo z archeologických sond S18 a S19 do zipových sáčků, odběr pomocí krabic nebyl možný z důvodu nesoudružnosti vzorkovaných sedimentů. Profil v nivě u Staré Rudné byl odebrán ručním vrtákem (výrobce Eilkamp), a to pomocí otevřeného žlabu o délce $100 \mathrm{~cm}$ a o průměru $7 \mathrm{~cm}$. Vrtány byly dva paralelní vrty s překryvem, aby byla zajištěna kontinuita odebraného profilu. Vrtná jádra byla na lokalitě zabalena, odběr vzorků pro pylovou analýzu a datování proběhl v laboratoři. Vzorky pro pylovou analýzu byly zpracovány standardní acetylační metodou včetně použití kyseliny fluorovodíkové k odstranění křemičitanů (Moore et al. 1999). Pylový diagram byl nakreslen v programu POLPAL (NalepkaWalanus 2002). Radiokarbonové datování bylo provedeno metodou AMS v laboratoři Laval University, Quebec, Kanada. K datování byly použity rostlinné makrozbytky, v př́ípadě jejich absence uhlíky. Kalibrace výsledků byla provedena v programu OxCal 4.3 (Bronk Ramsey 2009) s použitím data setu IntCal13 jako kalibrační křivky (Reimer et al. 2020).

\section{Popis rýžoviště}

Jižní část Andělskohorského rudního revíru je odvodňována vodními toky Starou vodou, Zlatým potokem a Žebráckým potokem (obr. 3). Zvláště na dvou posledně jmenovaných jsou zachovány četné pozůstatky po rýžování (obr. 3:R1). Rýžoviště byla jistě i na Staré vodě, ale vzhledem k tomu, že protéká přes intravilány Suché Rudné a Staré Vody, jsou dnes již aplanována. Jejich relikty byly zastiženy při výkopových pracích v Suché Rudné (obr. 3:SR6, SR3, R2; Novák-Kuba 1990; Večeřa-Malík-Zezula 2014). Další zachované rýžoviště se nachází až při soutoku Staré Vody a Černého potoka (obr. 3:R3). Asi o kilometr dále je poslední zachovaný relikt rýžoviště na Černém potoce na severozápadním okraji Nové Vésky, který byl zvolen jako předmět výzkumných prací (obr. 3:R4). Lze sice předpokládat, že rýžoviště byla i dále směrem k Bruntálu (obr. 3:R5), ale jsou dnes již aplanovaná a jejich existenci prozrazují pouze ojedinělé zbytky sejpů na pravém břehu Černého potoka v blízkosti katastrální hranice mezi Malou Véskou a Starým Městem u Bruntálu.

Rýžoviště při severozápadním okraji intravilánu Nové Vésky je nejbližším zachovaným rýžovištěm u Starého Města. Pozůstatky po rýžování se nachází na pravém břehu Černého potoka na ploše $800 \times 70 \mathrm{~m}$, která je rozdělena silnicí Nová Véska - Stará Rudná na dvě části. Porost tvoří převážně jehličnaté stromy, v centrální části postižené polomem, částečně již odklizeným.

Rýžoviště detailně popsal Jaromír Novák (1990, př́iloha II-6-1). Uvádí, že rýžoviště je v historické literatuře spojováno se vznikem původního Bruntálu (dnes Staré Město), ale bez náležitých odkazů. Rýžoviště rozděluje na tři části. V severní části se zachoval souvislý úžlab šířky až $5 \mathrm{~m}$ lemovaný po východní straně protáhlými, přerušovanými odvaly výšky kolem $1 \mathrm{~m}$. Ve střední části severně od silnice předpokládá dobývání rýžovnickými poli do hloubky jednoho metru po stranách rozplavovacího kanálu. Ten je lemován na západě nízkými protáhlými haldami a na východě velkými haldami výšky až $2 \mathrm{~m}$. Prostor protínají př́ičné mladší potůčky. $\mathrm{V}$ jižní části popsal tři rovnoběžné zářezy šířky $2 \mathrm{~m}$ a hloubky do $2 \mathrm{~m}$, mezi nimiž jsou protáhlé haldy výšky kolem $2 \mathrm{~m}$. Postup těžby předpokládá od jihu k severu s postupným zařezáváním do svahu a prohlubováním dobývek pod úroveň nivy.

Na základě digitálního modelu reliéfu pořízeného v rámci výzkumu (obr. 4 a 5) je možné popis rýžoviště upřesnit. Hlavní pozůstatky po rýžování severně od silnice se nachází mezi západním břehem údolí Černého potoka a lesní cestou severojižního směru. Mezi touto cestou 


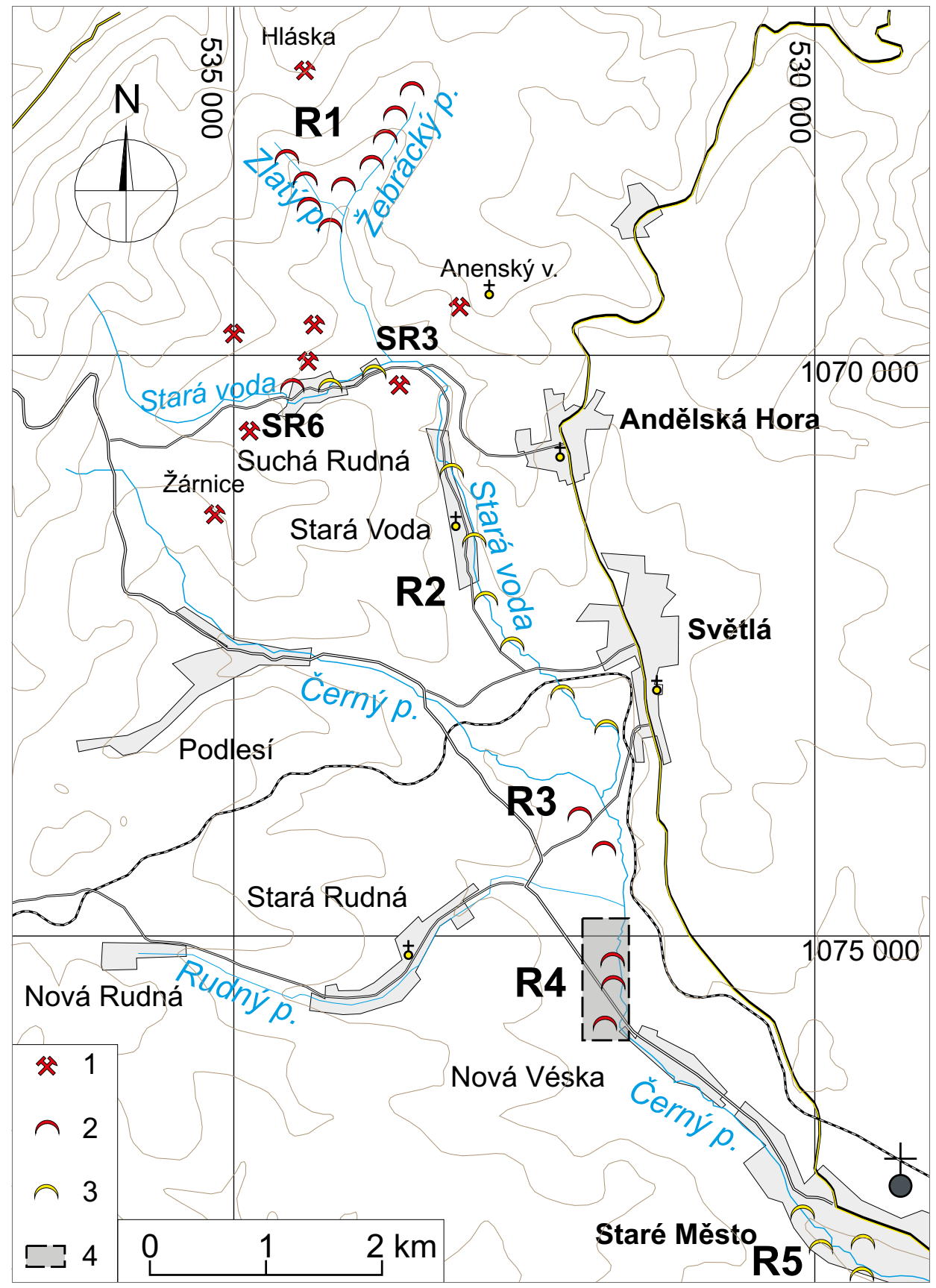

Obr. 3. Mapa rýžovišt' na Staré vodě a Černém potoku. 1 - místa s pozůstatky těžby primárních ložisek; 2 - doložená rýžoviště; 3 - potenciální místa rýžovišt'. Autor J. Večeřa

Abb. 3. Karte mit Goldseifen an den Bachläufen Stará voda und Černý potok. 1 - Stellen mit Abbaurelikten primärer Lagerstätten; 2 - belegte Goldseifen; 3 - potenzielle Goldseifenstellen. Autor J. Večeřa. 
a řečištěm Černého potoka jsou relikty pouze ve střední části, jinak je terén zarovnaný s náznaky původního řečiště nebo vodních kanálů. Jižně od silnice jsou pozůstatky těžby pouze v úzkém lemu, širokém asi $50 \mathrm{~m}$, pod západním břehem údolí Černého potoka a směrem k jihu jsou zcela aplanovány intravilánem Nové Vésky.

Severní konec rýžoviště (obr. 4, plocha 1) tvoří úzký výběžek katastrálního území Malé Vésky do katastru Staré Rudné. Na východě je omezeno lesní cestou a na západě hranou vyššího nivního stupně. Prochází jím několik vodních kanálů severojižního směru, které se na jižním konci stáčí k jihovýchodu a ukončují plochu této části rýžoviště. Kanály jsou po své východní straně lemovány nevysokými odvaly. Od nejvyššího kanálu směrem k západu je raženo několik krátkých prospekčních zářezů do vyššího nivního stupně, přičemž jeden byl následně využit jako prrístupová cesta do obdélníkového kamenolomu. Z pozice kanálů a odvalů lze vyvodit, že těžba probíhala frontálně směrem k západu, přičemž těžený materiál byl skopáván do vodního kanálu vedeného při úpatí těžební stěny, čímž se na protilehlé straně kanálu tvořily lemy odvalů hlušiny. V jižní části plochy je kanál lemován po obou stranách, což by mohlo svědčit o selektivní těžbě pohřbeného říčního ramene s ukládáním hlušiny po obou stranách.

Jižně od plochy 1 se nachází prostor značně plochého terénu (převýšení 2,5 m) $\mathrm{s}$ chaoticky rozmístěnými haldami nepřevyšujícími $2 \mathrm{~m}$ (obr. 4, plocha 2), kterou nelze za současného stupně poznání spolehlivě interpretovat. Jižně je omezena plochou (obr. 4, plocha 3), která je protažena ve směru západ-východ a je poměrně rovná, s náznaky drobných úzkých valů protažených $\mathrm{v}$ tomto směru a náznaky zářezů vzniklých proudící vodou po spádnici (splachy). Jedná se pravděpodobně o nejmladší prostor modelovaný vodou, která přitekla z nevýrazného údolíčka ze západu. Šířka takto ovlivněného prostoru je asi $20 \mathrm{~m}$ a směrem $\mathrm{k}$ východu se vějířovitě rozšiřuje na $50 \mathrm{~m}$ a je ukončena vyklenutou haldou s přerušením uprostřed (odtok), která by mohla být zbytkem výplavového kužele nebo nahrnutého materiálu, pokud měl přítok vody př́ivalový charakter.

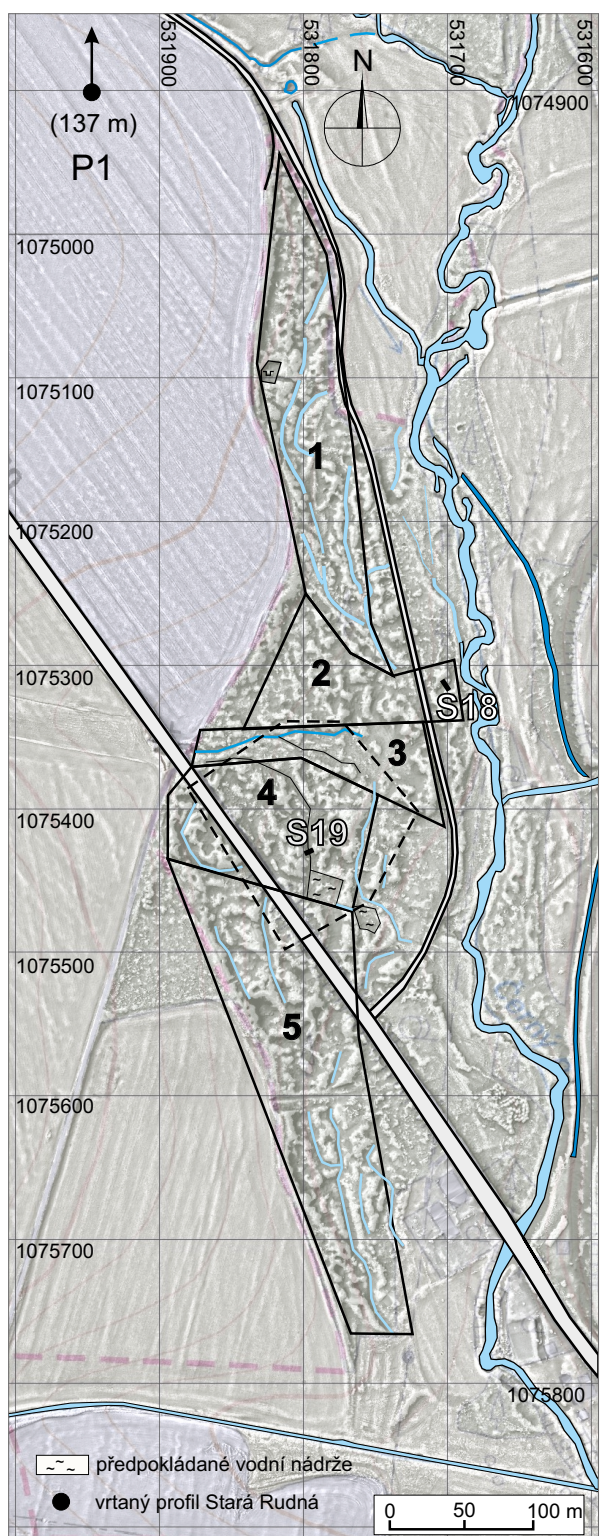

Obr. 4. Rýžoviště v severozápadní části katastru Nové Vésky. Digitální model reliéfu (DMR) z dat laserového leteckého skenování (LLS) v kompozitní vizualizaci. Vyznačeny jsou sondy archeologického výzkumu, plocha zaměřená metodou pozemního laserového skenování (přerušovaná čára) a údaje k lokalizaci vrtaného profilu v k. ú. Stará Rudná. Podkladová data CzechGlobe, vizualizace O. Malina.

Abb. 4. Goldseife im nordwestlichen Teil des Katasters von Nová Véska. Digitales Reliefmodell (DMR) anhand von Airborne-Laserscanningdaten (LLS) in zusammengesetzter Visualisierung. Gekennzeichnet sind die Sondierschnitte der archäologischen Grabung, die mittels terrestrischem Laserscanning vermessene Fläche (gestrichelte Linie) und die Angaben zur Lokalisierung des Bohrprofils im Katastergebiet Stará Rudná. Datenvorlage CzechGlobe, Vizualisierung O. Malina. 


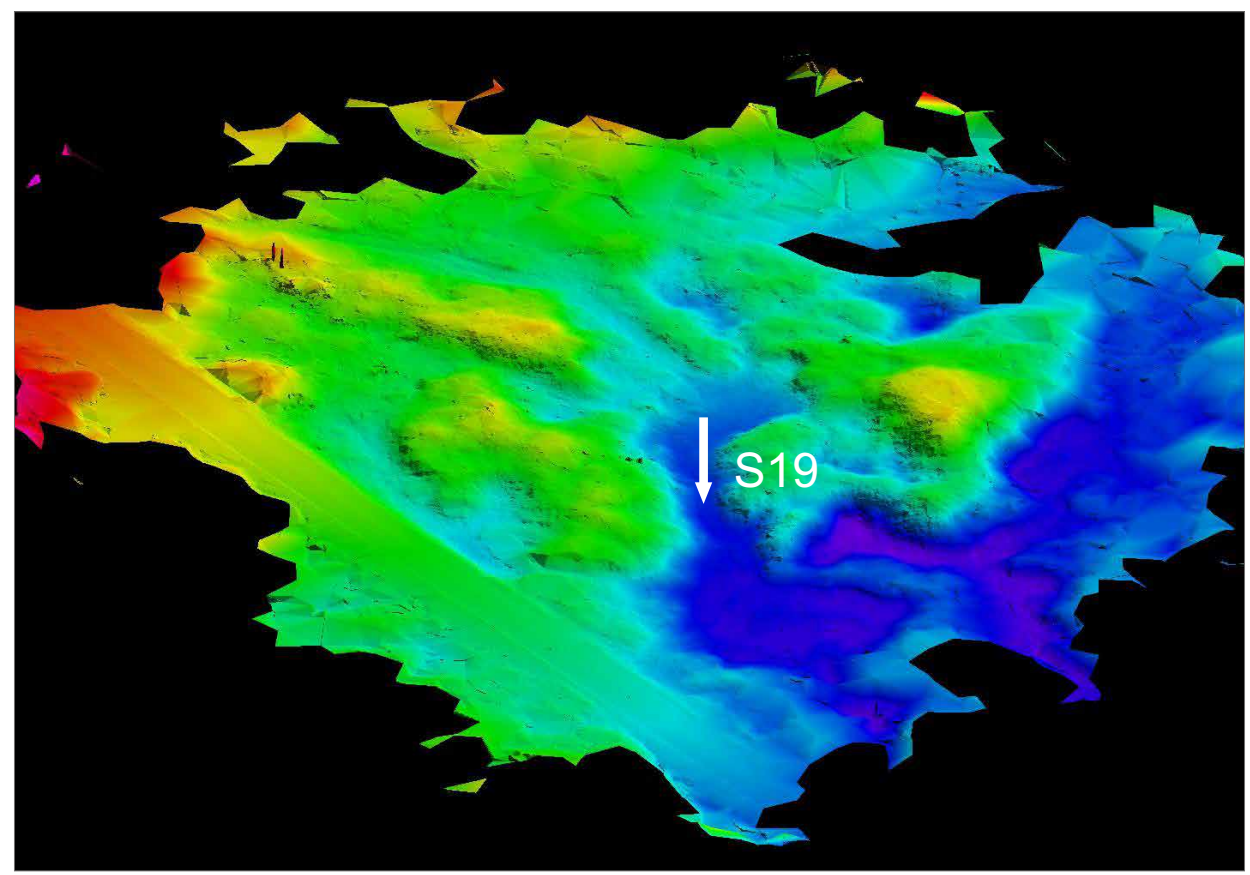

Obr. 5. Nová Véska. Stínovaný model území zaměřeného metodou pozemního laserového skenování. Pohled od jihu. Autor J. Tejkal, upravil M. Zezula.

Abb. 5. Nová Véska. Schattenmodell des mittels terrestrischem Laserscanning vermessenen Gebietes. Blick von Süden. Autor J. Tejkal, Bearbeitung M. Zezula.

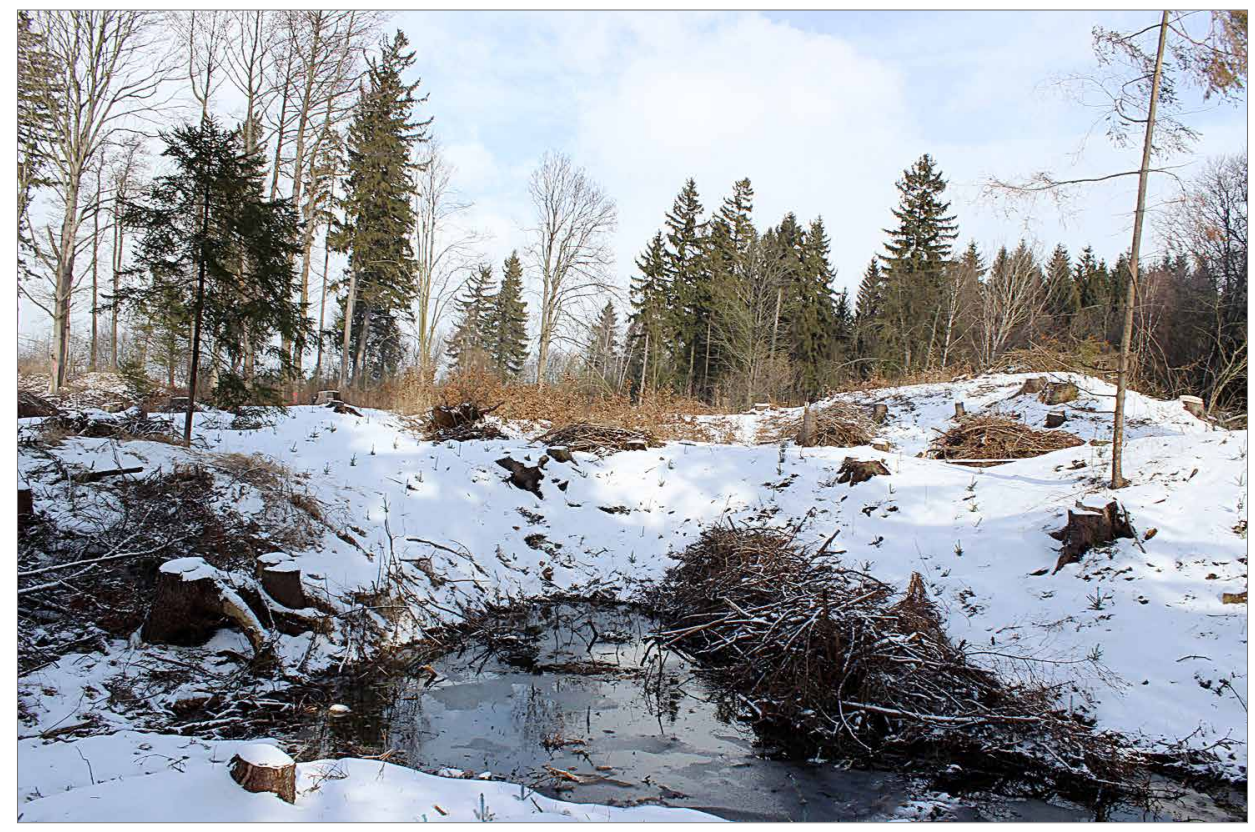

Obr. 6. Nová Véska. Pohled na skenovanou část rýžoviště od jihozápadu. Foto J. Brhelová, 2020.

Abb. 6. Nová Véska. Blick auf den gescannten Teil der Goldseife von Südwesten. Foto J. Brhelová, 2020. 
Směrem k jihu následuje prostor $(130 \times 90 \mathrm{~m})$ rozdělený silnicí a tvořený nejvýraznějšími konvexními tvary výšky až $4 \mathrm{~m}$, bez zřetelnějšího systému (obr. 4, plocha 4). Nelze vyloučit, že se jedná o povrchovou dobývku, jejíž jihozápadní stěna je poničena silnicí, a zachovaly se pouze odvaly a skrývky pod ní. Středem zaměřené plochy (obr. 5) probíhá zářez interpretovaný jako vodní kanál (571 m n. m.). Kanál ústí v rozšířeném sníženém místě, které bylo pravděpodobně vodní nádrží. Přes kanál byla vykopána rýha (S19), jež zastihla po obou stranách haldy výšky 2 až $3 \mathrm{~m}$. Západní je tvořena silně zahliněnými štěrky, místy s úlomky převážně kulmské břidlice, odpovídající deluviálním sedimentům. Východní svah je tvořen červenohnědou spraší s úlomky kulmské břidlice a štěrčíkem. Klasické vytříděné sedimenty vznikající při rýžování zastiženy nebyly. Povrch nejvyšší části haldy východně od kanálu, dosahující výšky $4 \mathrm{~m}$, je tvořen hrubým materiálem. V detailním modelu (obr. 7) lze pozorovat, že odvaly byly vršeny v několika etapách (výšková úroveň 572,5 / 573,7 m, 573,5 / 574,5 m a 575 m). Popisovaná plocha přerušuje vodní kanály interpretované severně a jižně od ní, což může svědčit o tom, že se jedná o nejmladší fázi těžby.

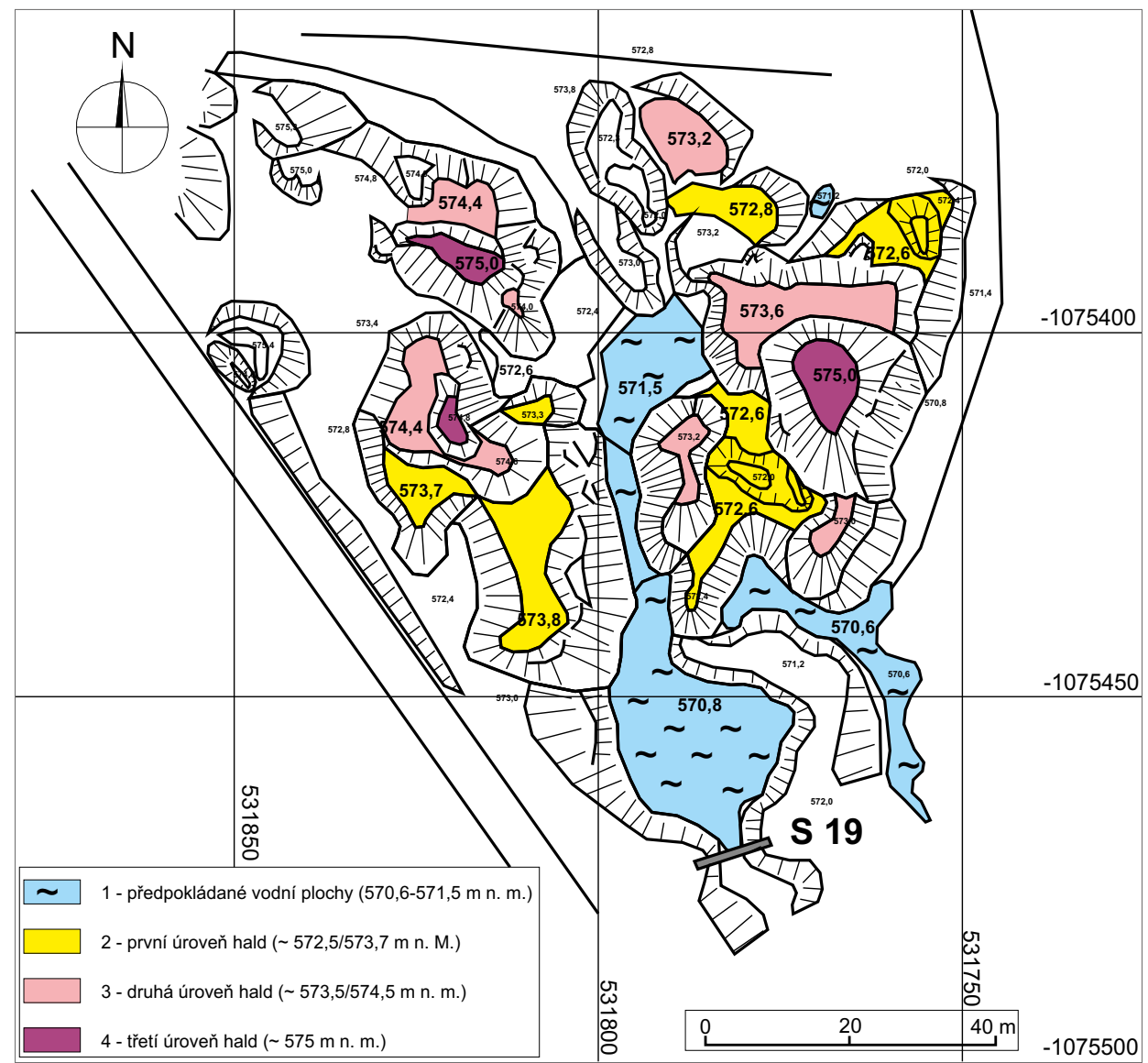

Obr. 7. Nová Véska. Interpretace reliéfu části rýžoviště zaměřeného metodou pozemního laserového skenování. Autor J. Večeřa.

Abb. 7. Nová Véska. Interpretation des Reliefs des mittels terrestrischem Laserscanning vermessenen Teils der Goldseife. Autor J. Večeřa. 
Jižně od plochy 4 je úzký pruh pozůstatků po těžební činnosti šiřky asi 50 m lemující v délce 350 m západní břeh údolí Černého potoka (obr. 4, plocha 5). Charakter těžby je obdobný jako na ploše 1, na rozdíl od ní jsou zde dobře zachovány zářezy až menší povrchové dobývky do západního svahu i s př́islušnými odvaly nad nejvyšším vodním kanálem.

\section{Archeologický výzkum rýžoviště}

V rámci archeologického výzkumu byly otevřeny dvě ručně kopané sondy (S 18 a S 19), ${ }^{2}$ byly umístěny tak, aby postihly konvexní (haldy) i konkávní (kanály) terénní tvary ve vzájemném kontaktu. Podmínky výzkumu nebyly optimální, v hloubce 1,5-2,0 m nastupovala voda, dokumentaci profilů navíc ztěžovalo dřevěné pažení. V době výzkumu, v prosinci roku 2019, ale bylo možné v rýžovišti pracovat ve stabilních hydrologických podmínkách (bez přívalových dešt'ů) a v prostředí s redukovanou vegetací. V roce 2020 navázal na uvedené terénní práce odběr (vrtaného) profilu nivních sedimentů Černého potoka již na sousedním katastru Staré Rudné, avšak stále ještě v těsném kontaktu se zkoumaným rýžovištěm.

\subsection{Popis a interpretace nálezové situace}

Sonda $S 18$ o rozměrech $8,0 \times 0,9 \mathrm{~m}$ s hloubkou od jihovýchodu $240-150-230 \mathrm{~cm}$ byla situována ve východní, dnes převážně aplanované části plochy rýžoviště, prribližně $15 \mathrm{~m}$ od pravého břehu Černého potoka. Sonda byla položena zhruba kolmo na osu lineární sníženiny (zářezu) lemované z jihovýchodu i severozápadu oválnými haldami (obr. 9).

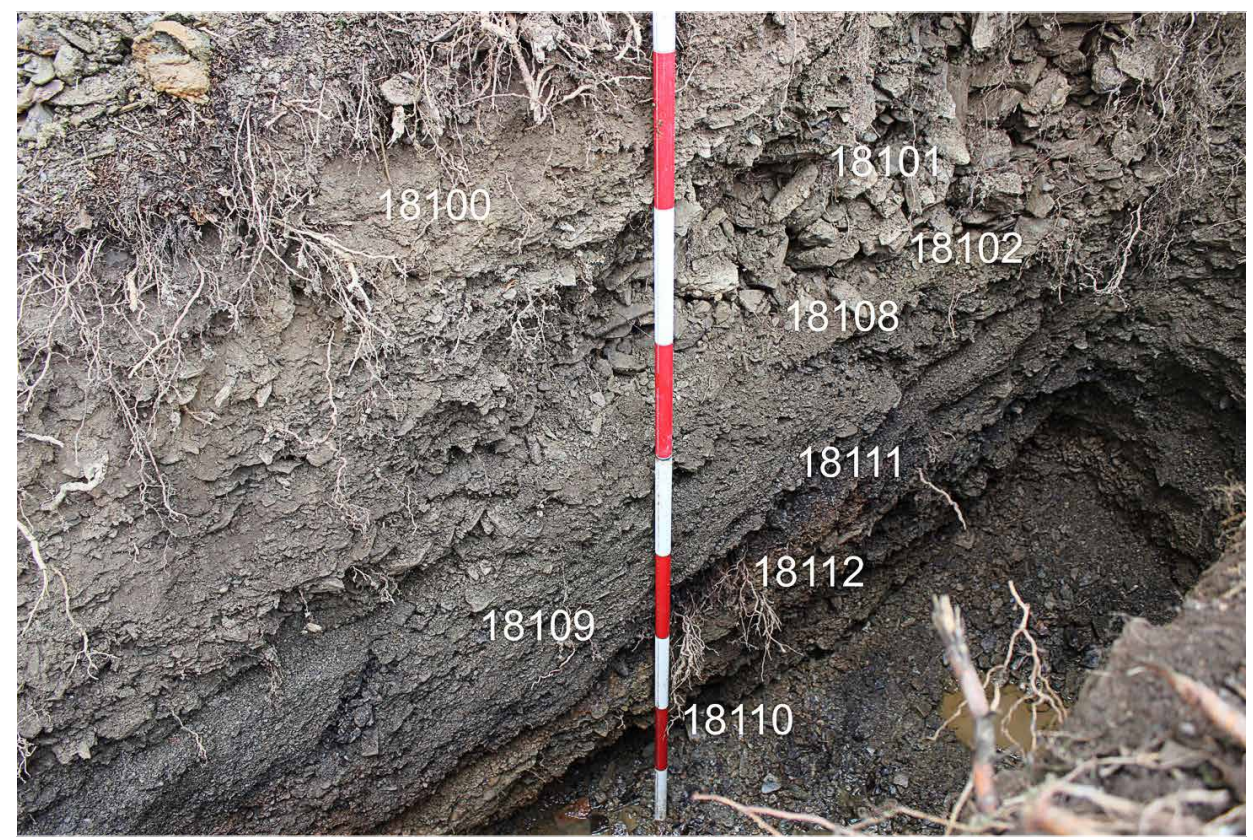

Obr. 8. Nová Véska. Detail stř́ídání hrubé a jemné štěrkové frakce v severní části sondy S18. Foto J. Brhelová.

Abb. 8. Nová Véska. Detail der abwechselnden groben und feinen Geröllfraktion im nördlichen Teil von Sondierschnitt S18. Foto J. Brhelová.

2 Číslování sond je navázáno na interní evidenci výzkumných prací projektu v daném roce. 
V metráži 0-3 m (jihovýchodní část rýhy) byl na bázi zastižen ulehlý hrubý načervenalý štěrk s valouny do $2 \mathrm{~cm} \mathrm{~s}$ doškovitým uspořádáním, který představuje původní nepřemístěný aluviální sediment (18105) ukládaný prrírodně v proudící vodě. Sediment tvoří mírně převažující kulmské horniny (50 \%), devonské horniny (45\%) a křemen (5\%). Převažuje písčitá frakce do $1 \mathrm{~mm}(44 \%)$ nad jemným štěrčíkem do $1 \mathrm{~cm}(33 \%)$ a štěrkem do $5 \mathrm{~cm} \mathrm{(23 \% ).} \mathrm{Hrubý} \mathrm{štěrk} \mathrm{nad}$ $5 \mathrm{~cm}$ není zastoupen. $Z$ kulmských hornin převažuje zelenošedá jílovitá břidlice až prachovec s častými žlutohnědými povlaky, tvořící tenké deskovité úlomky s ohlazenými až zaoblenými hranami. Prachovec není tak výrazně deskovitý. Droba je zastoupena pouze několika oválenějšími úlomky. Devonské horniny tvoří pestrou škálu petrografických typů, pro něž je společné výrazné oválení. Převažují tvary ve tvaru penízků do $2 \mathrm{~cm}$, př́ípadně doutníkovitého tvaru u grafitických fylitů. Nejčastější jsou kromě grafitických fylitů zelenošedé muskovitické břidlice, někdy páskované, přičemž světlé zelenošedé kvarcitické vrstvičky tvoří někdy samostatné valouny podobné stejně zbarveným spilitům. Bazické vulkanity jsou zastoupeny hrubozrnnými hnědozelenými typy se světlými šlíry. Část hornin je postižená karbonatizací, projevující se drobnými světlehnědými očky, dodávajícími hornině kropenatý vzhled. Zcela ojediněle byla v odebraném vzorku zastoupena načervenalá silně zvětralá okatá rula (1 kus) a pravděpodobně výrazně usměrněný zelený fylonit.

Nad vrstvou 18105 se nachází asi padesáticentimetrová poloha šedého jílovitého štěrkopísku upadající k západu, s mírnou převahou písčité frakce (39 \%) nad jemným štěrčíkem (30 \%) a štěrkem (31\%). Svrchní část je spíše červenohnědá, méně jílovitá (18114), ve spodní části přibývá jílovité složky (18104) a na bázi je tenká vrstva s převažujícím šedým jílem. Výrazný rozdíl je v zastoupení hornin hrubé frakce. Ze $70 \%$ je tvořena kulmskými horninami, které jsou jen mírně opracované a zachovávají si svůj původní tvar. Devonské horniny tvoří asi $20 \%$, z čehož nejčetnější jsou břidlice a fylity s grafitem tvořící drobné dobře oválené doutníkovité nebo penízkovité tvary. Úlomky i valouny jsou často pokryty červenohnědou patinou. Kromě bazální jílovité polohy nemá sediment žádné znaky ukládání ve vodním prostředí. Jedná se pravděpodobně o výkliz přerýžovaného materiálu.

Svrchní část o mocnosti asi $1 \mathrm{~m}$ (18103) tvoří nevytříděný zahliněný hnědošedý sediment s ostrohrannými úlomky břidlic, který lze interpretovat jako skrývku deluvia. Směrem k severozápadu na tuto vrstvu přiléhá vrstva šedého jílu (18107), v němž s hloubkou přibývá drobných okrově zbarvených čoček a závalků (18106). Obsahuje na omak menší podíl písčitého podílu
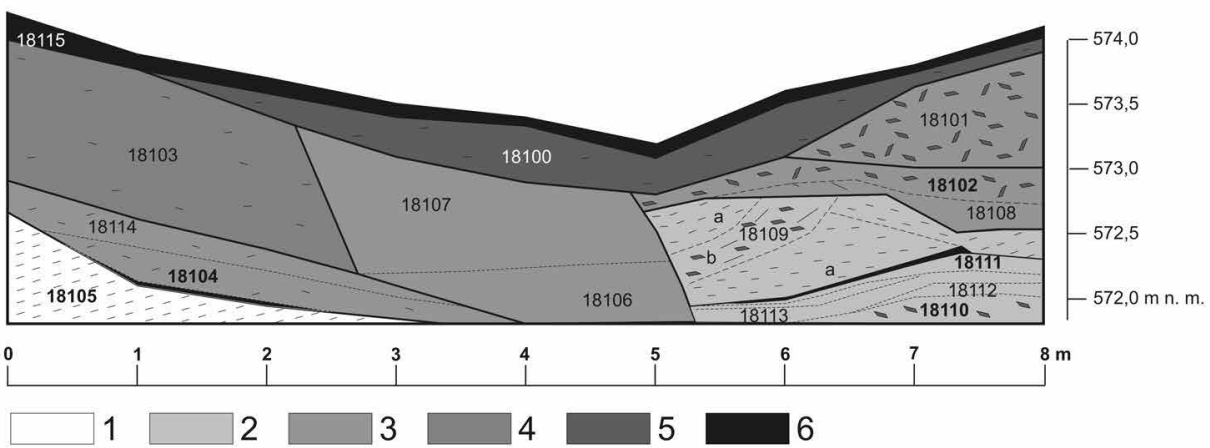

Obr. 9. Nová Véska. Schematizovaný profil sondy S18. 1 - aluvium; 2 - uloženiny vzniklé po rýžování; 3 - přemístěný materiál po rýžování (po sítování, po odkalování, po rýžování); 4 - skrývka; 5 - splachy; 6 - humusová vrstva. Z vrstev se zvýrazněným číslem (tučně) byly odebrány vzorky na granulometrii. Autoři J. Brhelová a J. Večeřa.

Abb. 9. Nová Véska. Schematisiertes Profil von Sondierschnitt S18. 1 - Alluvium; 2 - nach dem Auswaschen entstandene Ablagerungen; 3 - nach dem Sieben, Entschlammen und Auswaschen verlagertes ausgewaschenes Material; 4 - Deckschicht; 5 - Anspülungen; 6 - Humusschicht. Aus den in Fettschrift hervorgehobenen Zahlen wurden Proben für die Granulometrie entnommen. Autoren J. Brhelová und J. Večeřa. 
a ostrohranné úlomky. Svým charakterem odpovídá materiálu, který se při odkalování před rýžováním mohl usazovat $\mathrm{v}$ odkalovacích jímkách, ale absence texturních znaků typická pro ukládání sedimentu ve vodním prostř̌edí svědčí o druhotném přemístění na svah tvořený vrstvou skrývky (18103), např́íklad při čištění takové jímky.

Severozápadní část sondy (metráž 5-8 m) zastihla antropogenní sedimenty různých zrnitostí vzniklé při procesu rýžování. Nejníže je poloha žlutohnědých až rezavých sedimentů. Bázi tvoří hrubý sediment (18110) s výraznou převahou štěrku až hrubého štěrku (60 \%) a jen malým podílem pískové frakce (13\%). Složením odpovídá jílovitému štěrkopísku (18104) z jihovýchodní části rýhy (70 \% kulmské horniny, $20 \%$ devonské horniny a $10 \%$ křemen). Zelenošedé kulmské jílovité břidlice tvoří veškerý podíl nad $5 \mathrm{~cm}$. Úlomky jsou hnědě patinované, mají ohlazené hrany, ale zachovaný původní tvar. Devonské horniny tvoří jen menší hnědě patinované valounky různých tvarů, z nichž část je rozbitá. Směrem k povrchu se štěrčík zjemňuje (18112), až přechází do rezavých neulehlých čistých vytříděných, mírně zajílovaných štěrčíků $(18113,18111)$, v nichž již mírně převažuje písčitá frakce (41 \%) nad jemným štěrčíkem (30 \%) a štěrkem (29 \%). Také narostl podíl devonských valounků (33 \%) na úkor kulmských hornin $(60 \%)$ a křemene $(7 \%)$. Materiál představuje přepracovaný povrch dna vodoteče tvořený kulmskými břidlicemi, včetně aluviálního sedimentu, který zapadl do spár břidlic, což dokládá absence větších devonských valounků a patina většiny úlomků.

Nad vrstvou rezavých štěrků je vrstva šedých až hnědošedých čistých písků s podílem drobného štěrčíku (18109a). Na jejich styku je tenká výrazně rezavá poloha zbarvená limonitem. Uvnitř vrstvy je pás tvořený hrubším materiálem (18109b). Od níže i výše ležící vrstvy se liší jednak čistotou (jílová složka zastoupena pouze minimálně), ale hlavně výraznějším úklonem ploch upadajících převážně k jihovýchodu, který připomíná křižzvé zvrstvení sedimentů. Tento sediment lze interpretovat jako sypaný produkt vzniklý rýžováním.

Výše leží vrstva tmavošedého zajílovaného štěrčíku (18108) bez náznaku usměrnění, který výše přechází do hrubého materiálu s výraznou převahou štěrku a hrubého štěrku (18102) tvořícího $55 \%$. Drobný štěrčík a písčitá frakce je zastoupena jen 20, respektive $25 \%$. Hrubý štěrk (nad $5 \mathrm{~cm}$ ) je tvořen deskami jílovité kulmské břidlice a dvěma valouny zeleného bazika se světlými šlíry. Ve štěrku je poměr kulmských a devonských hornin vyrovnaný. Podíl křemene činí asi $10 \%$ a $20 \%$ tvoří neurčitelné kusy (výrazná hnědá patina na všech úlomcích). Svrchní část polohy tvoří separované kameny kulmských břidlic do $20 \mathrm{~cm}$ (18101). Jedná se pravděpodobně o materiál vzniklý vylámáním a hrubým přesítováním skalního podloží vodního toku (patina).

Snížený střed rýhy nad výše popsanými vrstvami je vyplněn hnědošedou sprašovou přeplavenou hlínou s jemným štěrčíkem a úlomky (18100), která pokryla terén při záplavách (povodňový horizont). Vše je pak překryto tenkou tmavohnědou humusovou vrstvou (18115).

V jihovýchodní části sondy S18 byl zastižen na bázi přírodní aluviální sediment. Nad ním je vrstva výklizu přerýžovaného materiálu a výše deluviální skrývka, na níž byly deponovány jíly po odkalování materiálu určeného k rýžování. V severozápadní části jsou zachyceny různé typy sedimentů vznikajících při rýžování. Dle zastoupených hornin a jejich vzhledu byl hlavním předmětem těžby rozvětralý skalní podklad, v němž se zachytila část aluviálního sedimentu. Svrchní část profilu uprostřed rýhy je tvořena hlinitým povodňovým sedimentem vzniklým po ukončení rýžování.

Sonda $S 19$ s rozměry $6 \times 1 \mathrm{~m}$ a hloubkou od západu $190-110-200 \mathrm{~cm}$ byla položena ve střední části komplexu rýžoviště, do plochy zaměřené pozemním laserovým skenováním, jejímž středem probíhá zářez interpretovaný jako vodní kanál $(571 \mathrm{~m} \mathrm{n}$. m.). Sonda byla umístěna kolmo na osu vodního kanálu a zčásti zasáhla i dvě haldy o výšce 2 až $3 \mathrm{~m}$ po jeho stranách (obr. 10).

V západním konci rýhy byl zastižen jemný zajílovaný světlehnědý materiál (19101) s ostrohrannými úlomky převážně kulmské břidlice a závalky žlutohnědého jílu upadající k východu, interpretovaný jako skrývka deluvia, tvořící haldu za západním okrajem rýhy. Povrch je pokryt asi dvaceticentimetrovou vrstvou tmavšího hlinitého sedimentu s úlomky břidlice (19103), která je pravděpodobně zbytkem humózního pokryvu haldy. Ve východní části rýhy byl na bázi zastižen 

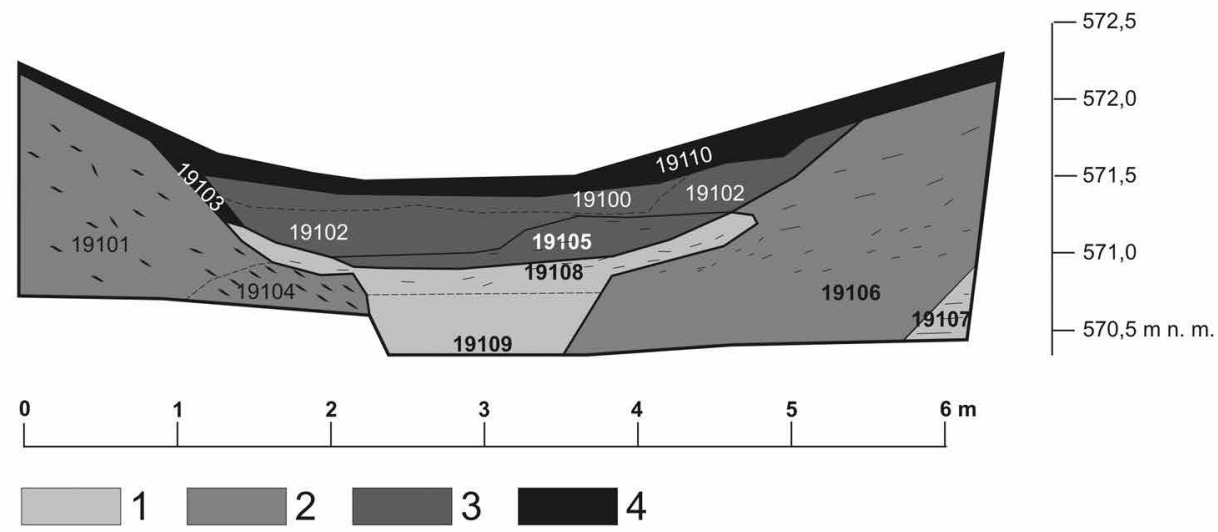

Obr. 10. Nová Véska. Schematizovaný profil sondy S19. 1 - uloženiny vzniklé po rýžování; 2 - skrývka; 3 - splachy; 4 - humusová vrstva. Z vrstev se zvýrazněným číslem (tučně) byly odebrány vzorky na granulometrii. Autoři J. Brhelová a J. Večeřa. Abb. 10. Nová Véska. Schematisiertes Profil von Sondierschnitt S19. 1 - nach dem Auswaschen entstandene Ablagerungen; 2 - Deckschicht; 3 - Anspülungen; 4 - Humusschicht. Aus den in Fettschrift hervorgehobenen Zahlen wurden Proben für die Granulometrie entnommen. Autoren J. Brhelová und J. Večeřa.

čistý materiál s valouny do $5 \mathrm{~cm}$ a kusy křemene do $15 \mathrm{~cm}$ (19107) o maximální mocnosti v čele rýhy $40 \mathrm{~cm}$. Převažuje písčitá frakce do $1 \mathrm{~mm}$ (38 \%), hrubé úlomky a valounky nad $1 \mathrm{~cm}$ tvoří jen asi $20 \%$ materiálu, v němž výrazně převažují kulmské horniny $(58 \%)$ zastoupené jílovitými břidlicemi až prachovci světle zelenošedé barvy s ohlazenými hranami a mírně zvlněnými plochami, které si zachovávají původní tvar (destičky většinou kosodélníkového tvaru). Podřadně jsou zastoupeny devonské horniny (17 \%) tvořící drobné valounky. Jde převážně o tmavošedý grafitický fylit a šedou muskovitickou břidlici, často s karbonátovými hnědými očky. Ojediněle jsou zastoupena i zelená hrubozrnná bazika. Křemen (25\%) je bílý kavernózní. Podle složení se jedná o přepracovaný vytrríděný materiál. Celý zbylý profil je tvořen červenohnědou spraší s úlomky a šlíry štěrčíků (19106), tvořící haldu za východním okrajem rýhy. V hrubém materiálu je zastoupen pouze kulmský materiál s minimálním opracováním a křemen. Jedná se o deponovanou skrývku deluvia s výrazným zastoupením žlutohnědých sprašových hlín. Vlastní koryto mezi oběma haldami je vyplněno vrstvou šedohnědého až namodralého jílu $(19108,19109)$ s proměnlivým zastoupením světle žlutých závalků jemného písku, červenými šlíry a ostrohrannými úlomky. Zastoupení písčité frakce a jemného a hrubšího štěrčíku je vyrovnané (po 30-40 \%). V hrubší frakci jsou kulmské horniny zastoupeny 70-80 \%. Převažují světle zelenošedé jílovité břidlice tvořící destičky s hladkými plochami, bez výrazného ohlazení. Pouze droby (10\%) jsou výrazněji ohlazené. Devonské horniny jsou pestré, výrazně oválené do doutníkovitých tvarů (grafitické fylity) nebo kruhových destiček. Jedná se pravděpodobně o přepracovaný materiál - odpad vzniklý odkalením. Niveleta středu polohy je nižší než okraje, což může být způsobeno částečnou pozdější denudací. Výše je asi deseticentimetrová poloha šedohnědého jílu se závalky štěrčíku (19105), v níž se střídají šedé a rezavé pásky. Hrubší frakce je tvořena výhradně kulmským materiálem (85\%) a křemenem (15\%). Jedná se o přeplavený deluviální materiál se sprašovou hlínou. V západní části je částečně denudován a překryt asi třiceticentimetrovou polohou sprašové hlíny s ojedinělými úlomky horniny (povodňový horizont?). Spodní část vrstvy je hnědošedá, rezavě mramorovaná (19102), horní část je spíše hnědá (19100), v ose zářezu tmavohnědá, promíchaná s nejsvrchnější vrstvou, tvořenou humózním pokryvem (19110) s úlomky břidlice (půdní horizont).

Výrazné haldy po obou stranách rýhy jsou tvořeny skrývkovým materiálem (deluvium se sprašovými hlínami), přičemž ukládání západní haldy skončilo dříve (vytvoření humózního pokryvu). Ve východním rohu rýhy byl zastižen přesítovaný a přerýžovaný materiál (absence 
hrubé frakce a jílu). Vlastní kanál je vyplněn jemným jílem vzniklým odkalováním rýžovaného materiálu. Svrchní poloha sprašové hlíny může být již produktem splachů z výše ležícího údolí (dnes pole), nebo se jedná o povodňový horizont ukládaný při vyšším stavu vody v údolí.

Celkově lze dle provedených sond a rekognoskace okolí předpokládat, že aluvium Černého potoka je tvořeno pouze málo mocnou vrstvou aluviálních sedimentů s valouny devonských hornin a pouze ohlazenými hranami u kulmských hornin. Vlastním předmětem těžby bylo rozvětralé podloží, které sloužilo jako přírodní splav. Minimum aluviálního materiálu při poměrně velké šíri erodovaného koryta může souviset s ledovcovou činností, kdy při tání horských ledovců a firnových polí byl aluviální materiál odnesen a uchován jen v příhodných kapsách skalního podkladu. Prohloubením koryt Moravice a Bílé Opavy byla voda odvedena bokem a povodí Černého potoka neposkytovalo dostatečné množství vody k vytvoření většího množství aluviálního sedimentu.

\subsection{Pylové profily}

Zachování pylových zrn ve vzorcích odebraných v sondách S18 a S19 bylo špatné, pylová zrna byla poškozena a zkorodována. Zajímavostí je minimální podíl mikrouhlíků, ačkoliv se jednalo o krajinu využívanou lidmi. Zásadní vliv měly sedimentační podmínky na lokalitě, kde se ukládal anorganický materiál z proudící vody.

\subsubsection{Pylový profil sondy S18}

Analyzovaných šest vzorků ze sondy S18 (obr. 11:S18) ukazuje relativně uniformní pylové spektrum s dominantou dřevin přes $95 \%$, a to hlavně smrku (Picea) - přes $50 \%$. Druhým nejčastějším taxonem je jedle (Abies) s podílem až $30 \%$. Pylové spektrum ostatních druhů dřevin tvoří buk (Fagus), habr (Carpinus), jilm (Ulmus), lípa (Tilia), nebo dub (Quercus). Podobné pylové spektrum je zachyceno v rašelinných profilech z Jeseníků (Dudová et al. 2018), kde je smrk (Picea) nadhodnocený $\mathrm{v}$ pylovém záznamu, jelikož se jedná o lokálně rostoucí dřevinu na zamokřených

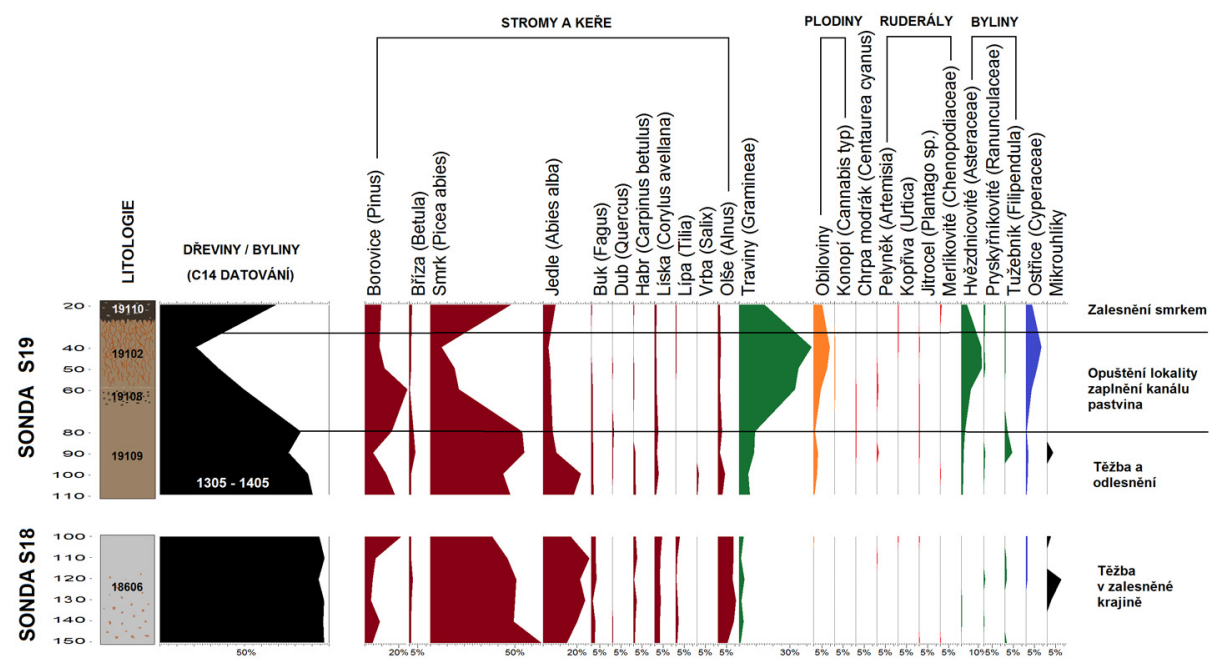

Obr. 11. Nová Véska. Procentický pylový diagram vybraných druhů ve vzorcích odebraných ze sond S18 a S19, ostřice jsou vyloučeny z celkové sumy a radiokarbobové datum je kalibrováno (AD). Autor L. Petr.

Abb. 11. Nová Véska. Prozentuales Pollendiagramm ausgewählter Arten in den aus den Sondierschnitten S18 und S19 entnommenen Proben, Sauergrasgewächse sind von der Gesamtsumme ausgenommen. Das Radiokarbondatum ist kallibriert (AD). Autor L. Petr. 
místech (Hájková et al. 2019), jako jsou rašeliniště nebo potoční nivy. Naopak olše (Alnus) je spíše typická pro potoční nivy než pro rašeliniště. Ve svrchním vzorku v hloubce $100 \mathrm{~cm}$ je vyšší podíl borovice (Pinus), což může indikovat začínající sekundární sukcesi lesa po těžbě. Byliny jsou zachyceny jen ojediněle s výjimkou pylu trav (Gramineae), které ale mohou indikovat i nivní a mokřadní vegetaci. Jinak se jedná hlavně o lokální mokřadní vegetaci, jako jsou ostřice (Cyperaceae), tužebník (Filipendula), spory kapradin (Polypodium typ), rdesno červivec (Polygonum persicaria), nebo o čeled' pryskyřníkovité (Ranunculaceae). Ruderální druhy zachycuje doslova jen několik pylových zrn merlíku (Chenopodiaceae), jitrocele kopinatého (Plantago lanceolata), kopřivy (Urtica) a pelyňku (Artemisia). Pyl obilovin reprezentuje jen jedno pylové zrno v nejsvrchnějším vzorku.

Profil ukazuje palynologický záznam původního prostředí a vegetace nivy potoka, do které prrišla těžba zlata. Lokálně v nivě dominoval smrk, případně jedle. Další dřeviny jsou méně časté a s výjimkou nejsvrchnějšího vzorku nejsou ani zachyceny druhy sukcesních stadií lesa. Naprosté minimum antropogenních indikátorů ukazuje, že zemědělské aktivity nebyly současné, nebo dokonce nepředcházely vlastní těžbě zlata, a tato těžba probíhala v primárním lidmi nenarušeném prostředí. Ruderální vegetace či mokřadní vegetace se v důsledku postupu těžby a dynamiky sedimentace materiálu neměla čas vyvinout tak, aby byla zachytitelná v pylovém záznamu. Spodní část profilu jemnozrnných sedimentů byla překryta další hlušinou, proto nelze $\mathrm{v}$ tomto profilu pozorovat další vývoj vegetace na lokalitě. Záznam z tohoto profilu je srovnatelný s výsledky paleoekologie areálu na úpravu zlatonosných sedimentů v Suché Rudné, kde byl také zachycen primární les $\mathrm{v}$ horské nivě bez další evidence odlesňování a zemědělských aktivit v okolí. Fáze těžby zlata evidentně předcházela vlastní zemědělské kolonizaci území.

\subsubsection{Pylový profil sondy S19}

Profil odebraný v sondě S19 (obr. 11:S19) zachycuje mnohem delší časový úsek než sonda S18, a to hlavně období po konci těžby zlata. Báze profilu v hloubkách 110 a $100 \mathrm{~cm}$ je prakticky identická se sondou S18. V lesní vegetaci převažuje smrk a jedle, ale je zde již vyšší podíl borovice. Spektrum bylin ukazuje, že v okolí místa se již rozvíjelo zemědělské zázemí středověkého osídlení podle zastoupení pylu obilovin. Jinak je zachycena mokřadní vegetace, která zachycuje pyl ostřic (Cyperaceae) a tužebníku (Filipendula). Radiokarbonové datování uhlíku získaného z vrstvy 19109 (hloubka $105 \mathrm{~cm}$ měřená od nejnižšího místa v rámci sondy) ukazuje po kalibraci na období let 1305 až 1405 (tab. 1), kdy se zaplňoval kanál po ukončení těžby. Naopak výrazně mladšs ${ }^{14} \mathrm{C}$ data získaná $\mathrm{z}$ nezuhelnatělých semen $\mathrm{z}$ téže vrstvy jsou v rozporu se stratigrafií vrstvy a také s palynologickým záznamem. Jejich výskyt ve vzorku je patrně způsoben kontaminací při odběru, nebo pocházejí z výsušných prasklin, případně dutin způsobených prokořeněním. Výrazné změny nastávají v hloubkách 80 a $90 \mathrm{~cm}$, kde klesá podíl pylu jedle (Abies), ale mírně přibývá smrku (Picea) a borovice (Pinus). Následně expanduje pyl trav, které se stávají dominantními v celém pylovém spektru. Naopak ustupuje pyl dřevin včetně smrku. Pravděpodobně dochází k lokální sukcesi, stabilizaci povrchu vegetace. Lokalita měla lokálně podobu mokřadu nejen podle vysokého podílu trav, ale hlavně podle pylu ostřic (Cyperaceae) a spor rašeliníku (Sphagnum). Okolní krajina je již plně zemědělsky využívána, zachycen je vyšší podíl pylu obilovin, ale také pyl konopí (Cannabis sativa typ). Nárůst pylu smrku a ústup pylu trav v hloubce $20 \mathrm{~cm}$ je daný zalesněním lokality smrkovou monokulturou. Podíl smrku se v pylovém záznamu neprojeví hned, jelikož smrk kvete až ve věku okolo 60 let. Proto mladé porosty, nebo vysázené smrkové monokultury, se v palynologickém záznamu neprojeví, na rozdíl od makrozbytků, kde se zachovávají smrkové jehlice. Jediný antrakologický vzorek vydal soubor uhlíků tvořený zejména uhlíky taxonu topol/vrba (pravděpodobně nějaký $\mathrm{z}$ mnoha druhů vrb rostoucí v bezprostřední blízkosti Černého potoka) s menší příměsí vlhko tolerujícího smrku.

Profil S19 zachycuje o něco mladší období než báze profilu S18, kde není vidět začínající zemědělské využivání krajiny. Jedná se o profil kanálu, který byl postupně zaplňován, a nikoliv 
Tab. 1. Nová Véska a Stará Rudná. Přehled radiokarbonových dat. Analýzy provedly KECK Carbon Cycle AMS Facility, Earth System Science Department, University of California, Irvine, USA, a Radiochronology Laboratory C.E.N. (Centre for Northern Studies), Université Laval, Quebec, Kanada. Př́́slušné protokoly jsou uloženy v archivu odboru archeologie NPÚ, ÚOP v Ostravě. Kalibrace (AD) L. Petr.

Taf. 1. Nová Véska und Stará Rudná. Überblick der Radiokarbondaten. Die Analysen wurden durchgeführt von KECK Carbon Cycle AMS Facility, Earth System Science Department, University of California, Irvine, USA und Radiochronology Laboratory C.E.N. (Centre for Northern Studies), Université Laval, Quebec, Kanada. Die entsprechenden Protokolle werden in der Abteilung Archäologie des Nationalen Denkmalamtes, Gebietsfachstelle Ostrava aufbewahrt. Kallibrierung (AD) L. Petr.

\begin{tabular}{|c|c|c|c|c|c|c|}
\hline Vzorek & Materiál & $\begin{array}{l}\text { Laboratorní } \\
\text { kód }\end{array}$ & $\begin{array}{l}\text { Kód externí } \\
\text { laboratoře }\end{array}$ & $\begin{array}{l}\text { Radiokar- } \\
\text { bonový věk } \\
(14 C) \text { BP }\end{array}$ & $\begin{array}{l}\text { Odchylka } \\
\text { měření }( \pm)\end{array}$ & $\begin{array}{l}\text { Kalibrovaný věk } \\
\text { BC/AD }(95.5 \%)\end{array}$ \\
\hline $\begin{array}{l}\text { Nova Véska, Sonda } 19, \\
105 \mathrm{~cm}(1)\end{array}$ & Semena & ULA-8895 & UCIAMS-230056 & 115 & 15 & 1687-1927 AD \\
\hline $\begin{array}{l}\text { Nova Véska, Sonda 19, } \\
105 \mathrm{~cm}(2)\end{array}$ & Semena & ULA-8896 & UCIAMS-230057 & 130 & 20 & 1680-1939 AD \\
\hline $\begin{array}{l}\text { Nova Véska, Sonda } 19, \\
105 \mathrm{~cm}(3)\end{array}$ & Uhlíky & ULA-8897 & UCIAMS-230058 & 595 & 15 & 1305-1405 AD \\
\hline Stará Rudná 53 cm & Semena & ULA-9552 & UCIAMS-244267 & 615 & 15 & 1302-1392 AD \\
\hline Stará Rudná 93 cm & Semena & ULA-9553 & UCIAMS-244268 & 745 & 15 & $1261-1287$ AD \\
\hline Stará Rudná 128 cm & Semena & ULA-9551 & UCIAMS-244266 & 785 & 15 & $1225-1274$ AD \\
\hline Stará Rudná 163 cm & Semena & ULA-10055 & UCIAMS-252810 & 690 & 20 & 1276-1386 AD \\
\hline
\end{tabular}

jednorázově překryt hlušinou jako profil S18. Na bázi je zachycena původní lesní vegetace, která byla po těžbě a odlesnění nahrazena otevřenou kulturní krajinou. Lokálně místo pravděpodobně nebylo př́mo zemědělsky využíváno a $\mathrm{k}$ jeho opětovnému zalesnění mohlo dojít až v moderní době.

\subsubsection{Vrtaný profil Stará Rudná}

Ve spodní části vrtaného profilu (obr. 12) odebraného severně od rýžoviště je v hloubkách 128 až $164 \mathrm{~cm}$ zachycena fáze mýcení lesa a intenzivní těžby zlata $\mathrm{v}$ povodí potoka. Radiokarbonové datum 1276 až 1386 v hloubce $163 \mathrm{~cm}$ spadá do počátků kolonizace území, ${ }^{14} \mathrm{C}$ datum v hloubce $128 \mathrm{~cm}$ v rozmezí let 1225-1274 (tab. 1) je nepatrně mladší než hlubší vzorek. Ukazuje to na dynamiku sedimentace danou intenzivní těžbou a rychlým odlesněním v povodí potoka, která vedla k redepozicím materiálu. Sediment má anorganický charakter s vyšším podílem hrubší frakce, to ukazuje na rychlou sedimentaci v nivě a intenzivní erozi v povodí. V celém profilu jsou zachyceny mikrouhlíky ze dřeva jako indikátor lidské činnosti. V pylovém záznamu zcela převažují dřeviny, a to hlavně jedle (Abies) a smrk (Picea). Méně častá je borovice (Pinus), buk (Fagus), vlhkomilná olše (Alnus) a některé další listnaté dřeviny, jako jsou líska (Corylus), habr (Carpinus) nebo dub (Quercus). Byliny jsou zachyceny jen minimálně, a to hlavně pylem trav, zcela ojedinělá jsou pylová zrna obilí, konopí (Cannabis), ruderálního pelyňku (Artemisia) a několika dalších druhů. Tato spodní zóna je srovnatelná se sondou S18 a spodními vzorky sondy S19, v nichž je zachycena fáze těžby zlata.

V následné části profilu v hloubce 57 až $122 \mathrm{~cm}$ má sediment stále anorganický charakter, ale již jemnější frakce. Radiokarbonové datování ukazuje stáŕí 1302-1392 v hloubce $55 \mathrm{~cm}$ (tab. 1), to odpovídá zhruba předpokládanému konci těžby zlata a začátku zemědělské kolonizace. V pylovém záznamu je vidět postupný pokles pylu dřevin v důsledku odlesnění. Ubývá hlavně 


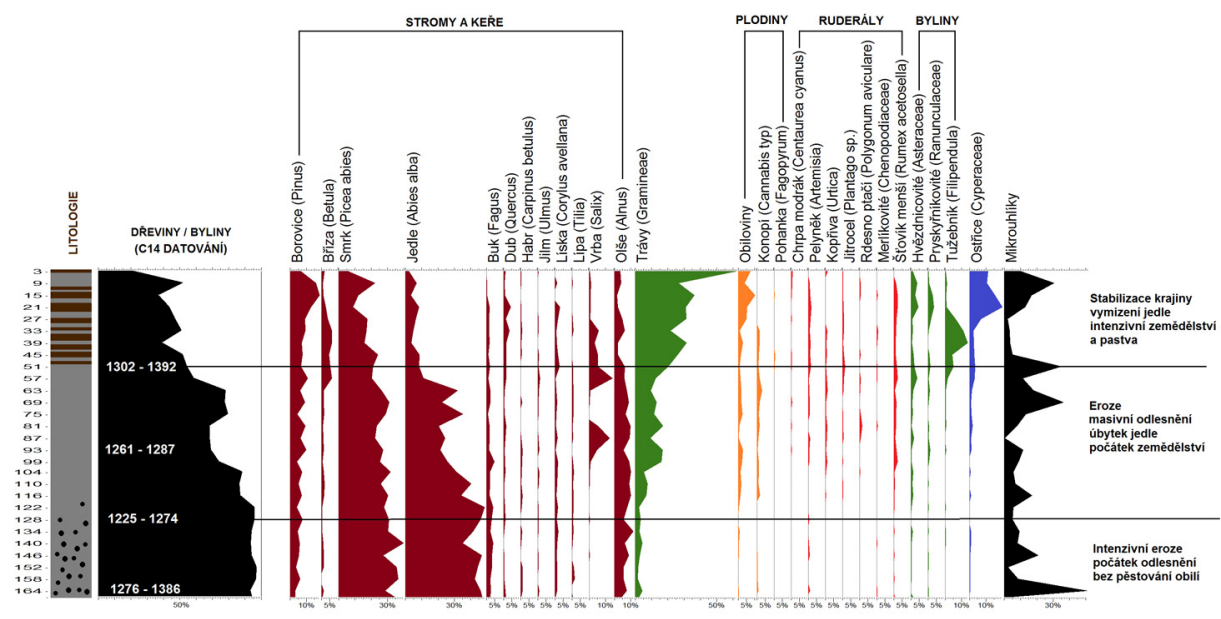

Obr. 12. Stará Rudná. Procentický pylový diagram vybraných druhů v odebraném profilu, ostřice jsou vyloučeny z celkové sumy. Radiokarbonová data jsou kalibrována (AD). Autor L. Petr.

Abb. 12. Stará Rudná. Prozentuales Pollendiagramm ausgewählter Arten im entnommenen Profil, Sauergrasgewächse sind von der Gesamtsumme ausgenommen. Die Radiokarbondaten sind kallibriert (AD). Autor L. Petr.

jedle (Abies), ostatní dřeviny mají stejné zastoupení. V pylovém spektru bylin přibývá pylu trav a objevují se výrazné křivky obilovin a konopí (Cannabis). Pěstování konopí není v současnosti typické pro vyšší nadmořské výšky horských oblastí, kde se nachází zkoumaná lokalita. Lidské aktivity v okolní krajině ukazují ruderální plevele, jako jsou merlíky (Chenopodiaceae), pelyněk (Artemisia), nitrofilní kopřiva (Urtica) a indikátory pastvy a sešlapu štovík menší (Rumex acetosella), jitrocel kopinatý (Plantago lanceolata) a rdesno ptačí (Polygonum aviculare). Toto období zachycuje začátek zemědělské kolonizace území, postupnou stabilizaci povrchu krajiny narušené intenzivní těžbou a extenzivní využíání krajiny pro pastvu.

Svrchní část profilu v hloubce 0 až $51 \mathrm{~cm}$, která je mladší než ${ }^{14} \mathrm{C}$ datum $1302-1392$, má odlišnou sedimentaci tvořenou vrstvami organického a jílovitého sedimentu. To ukazuje na změnu sedimentace, kdy převažuje lokální mokřadní vegetace a eroze z okolí je mnohem menší než v předchozím období. V pylovém záznamu klesá podíl dřevin, výrazně se mění skladba lesní vegetace. Výrazně klesá podíl jedle (Abies), dominantou se stává smrk (Picea). Ve vrchních vrstvách v nejmladším období prakticky mizí buk (Fagus), ale i řada listnatých dřevin, jako je líska (Corylus) nebo habr (Carpinus). Naopak se mírně zvyšuje zastoupení borovice (Pinus) a břízy (Betula). Tyto pionýrské dřeviny indikují obnovu narušených přirozených lesů. V pylovém spektru bylin se zvyšuje podíl trav; to nemusí indikovat jen okolní luční vegetaci, ale vzhledem k organickému sedimentu i lokální mokřadní vegetaci, podobně jako pyl ostřic (Cyperaceae). Zemědělské aktivity v okolí ukazuje pyl obilovin a konopí (Cannabis), v hloubce $27 \mathrm{~cm}$ mizí konopí, naopak se zvyšuje podíl obilovin. Pravděpodobně v novověku se přestalo pěstovat konopí a stoupla produkce obilí. Z pěstovaných plodin jsou zachycena jen ojedinělá pylová zrna pohanky (Fagopyrum). Ruderální a pastevní druhy jsou v podobném složení jako v předchozí části profilu a ukazují shodné využívání okolní krajiny. Odlišná je lokální mokřadní vegetace, kde jsou zachyceny vlhkomilné druhy, jako jsou tužebník (Filipendula ulmaria), ostřice (Cyperaceae) a pryskyřníkovité (Ranunculaceae), které ukazují vlhké louky a mokřadní stanoviště. Nejsvrchnější vzorek (hloubka $3 \mathrm{~cm}$ ) z vrstvy recentního opadu vykazuje velký podíl pylu trav a vymizení indikátorů sešlapu a pastvy. To indikuje změnu managementu vlhkých luk v posledních desetiletích z pastvy na intenzivní kosení motivované zemědělskými subvencemi. 


\section{Výsledky environmentálního výzkumu rýžoviště v Nové Vésce v kontextu poznatků z dalších lokalit na Bruntálsku}

Středověká kolonizace je zásadní změnou ve vývoji vegetace Jeseníků, která vedla k odlesnění a změně složení lesní vegetace. Projevuje se úbytkem dominantních dřevin, jako jsou jedle či buk, naopak se šírí pionýrská bříza a borovice jako raně sukcesní stadium lesa. Podobně se šírí i smrk, který je podporován lidskou činností. Zásadní změnou je rozšíření sekundárního bezlesí, zejména luční vegetace, což se projevuje nárůstem podílu bylin v pylových spektrech a hlavně jejich druhové bohatosti. Pole a ruderální vegetace, včetně indikátorů pastvy a sešlapu, jsou rovněž zásadní změnou zachycenou v pylovém záznamu, a to i v relativně člověkem nedotčených rašeliništích, například Rejvíz (Dudová-Hájek-Hájková 2010), díky přenosu větrem. Změny ve využívání krajiny v druhé polovině 20. století, jako je úbytek obyvatelstva, zánik sídel a opuštění orného zemědělství ve vyšších polohách, zatím nebyly studovány v paleoekologickém záznamu.

Rozsah alpinského bezlesí v nejvyšších partích Jeseníků není velký, ale jedná se o velmi zajímavé území zejména z hlediska biodiverzity, ochrany prŕírody a také vlivu člověka v minulosti a současnosti (Treml-Jankovská-Petr 2008). Kolísání horní hranice lesa a kontinuita bezlesí od konce doby ledové po současnost jsou důležité pro přežití glaciálních reliktů v Jeseníkách na relativně malém rozsahu primárního bezlesí (Rybníček-Rybníčková 2004). V mladším holocénu je jasná otázka lidského vlivu a prrípadného snížení horní hranice lesa. Ojedinělá lidská př́tomnost v pravěku je doložena několika archeologickými artefakty, a hlavně lidský impakt dokladují četné uhlíky v půdních profilech (Novák-Petr-Treml 2010). Nejstarší radiokarbonová data dokládají lokální požáry již v době železné. Nejstarší uhlík získaný z vrcholových partií Pradědu ukazuje na požárové události již v době římské (1. století n. 1.). Otázkou je, zda horské polohy byly ovlivňovány lidským hospodařením již tehdy, přímé doklady o osídlení horských údolí v této době totiž chybí. Hojné akumulace uhlíků v blízkosti Petrových kamenů naznačují, že toto specifické místo bylo ovlivňováno ohněm podstatně intenzivněji. Okolí význačného skalního útvaru je považováno některými autory (Waldhauser 1972) za kultovní místo. Maximum požárů pak spadá do raného a vrcholného středověku, v novověku se jejich četnost výrazně snižuje.

Vrcholně středověká kolonizace je viditelná $\mathrm{v}$ pylových spektrech $\mathrm{z}$ několika rašeliništ' přímo na horní hranici lesa (Rybníček-Rybníčková 2004; Novák-Petr-Treml 2010), kde se objevují indikátory sešlapu a pastvy, jako jsou jitrocel kopinatý (Plantago lanceolata) a štovík menší (Rumex acetosella-typ), které pravděpodobně indikují př́imo pastvu nad horní hranicí lesa. Mění se skladba lesní vegetace, ubývá jedle (Abies) a buku (Fagus), a naopak se šírí smrk (Picea) a borovice (Pinus) jako následek kácení lesa (a jeho sekundární sukcese), jež potlačuje původní klimaxové dřeviny. Dále se v pylových spektrech objevují přímé antropogenní indikátory, jako jsou obiloviny a jejich plevele chrpa modrák (Centaurea cyanus) a koukol (Agrostema githago), nebo pohanka (Fagopyrum esculentum) a len (Linum usitattisimum). To je následek odlesnění nižších poloh Jeseníků a transportu pylu větrem. V prŕípadě původu kleče (Pinus mugo) se potvrdilo, že byla vysázena v 19. století a nejedná se o relikt ze starého holocénu (Novák-Petr-Treml 2010).

\section{Exkurz: Suchá Rudná, archeologický výzkum 2014}

Doposud publikované poznatky bylo v posledních letech možné doplnit na základě analýzy vzorků odebraných v rámci archeologických výzkumů na Bruntálsku realizovaných v posledním desetiletí. Mimo výše prezentovaného výzkumu rýžoviště v Nové Vésce se jednalo o archeologický výzkum dobývky za penzionem Holzberg v Suché Rudné v roce 2014, datované na přelom 20. a 30. let 13. století (Večeřa-Malík-Zezula 2014; Malík-Večeřa-Zezula 2017).

Lokalita Suchá Rudná se nachází na okraji horské nivy potoka Stará Voda v nejvyšší nadmořské výšce ze zkoumaných lokalit (695 m n. m.). Výsledky pylové analýzy jsou publikovány $\mathrm{v}$ rámci monografie věnované těžbě zlata a počátkům osídlení Bruntálska (Kočár-Petr-Kočárová 2017), která shrnula také poznatky z archeologického výzkumu středověké dobývky odkryté za 
penzionem Holzberg. Zde můžeme shrnout, že několik bodových vzorků ukazuje podobný obraz vegetace na začátku kolonizace jako lokalita Nová Véska. V pylovém spektru převažuje smrk (Picea), častá je borovice (Pinus) a jedle (Abies). To je dané lokální převahou smrku v nivě na dně údolí. Ostatní dřeviny, jako jsou buk (Fagus), habr (Carpinus), lípa (Tilia), jilm (Ulmus) nebo dub (Quercus), jsou zachyceny zcela ojediněle, jejich podíl v pylovém spektru je podobný jako v přirozených profilech datovaných do mladšího holocénu (Dudová et al. 2018). Antropogenní indikátory a ruderální plevele jsou jen minimálně zachyceny, okolí lokality v době její existence nebylo ještě odlesněno. Pyl obilovin není prakticky zachycen, to vylučuje současnou existenci zemědělského zázemí těžebního areálu. Doloženo je velké množství mikrouhlíků původem hlavně ze dřeva, jako výsledek lidské činnosti. V souboru nezuhelnatělého dřeva převládají jehličnany horských lesů (jedle/smrk, smrk) tvořící $46 \%$ analyzovaných fragmentů. Lokální materiál z potoční nivy indikuje nález dřeva olše a jasanu (dohromady $17 \%$ ). Druhy pasek a lesních světlin indikuje nález dřeva lísky (36\%). V souboru uhlíků byly zachyceny pouze dominantní druhy horského lesa - smrk a jedle (dohromady $97 \%$ ) a z listnáčů buk (3\%). V souboru makrozbytků převládají druhy lesních porostů nad indikátory bezlesí. Zbytky druhů rostoucích v horských lesích tvořily zhruba $89 \%$ analyzovaných makrozbytků a $1 \%$ makrozbytků náleželo nivním lesním společenstvům - olšinám (olše lepkavá, dvojzubec). Dominantní byly zejména makrozbytky jehličnatých dřevin - smrk a jedle $\mathrm{s}$ malou příměsí buku. Z bylin (typických pro horské lesy) pak byla zaznamenána semena št’avele kyselého a knotovky červené. Zbytky druhů pasek a lesních světlin tvořily přibližně $9 \%$ a zahrnují druhy světlomilných dřevin - bříza, líska, bez černý, bez hroznatý, ostružiník a maliník. Indikátory antropogenního (člověka doprovázejícího) bezlesí tvořily pouhé $1 \% \mathrm{z}$ analyzovaných makrozbytků. Zjištěny byly dva druhy rumišt' a ruderalizovaných trávníků: merlík bílý a pryskyřník plazivý.

\section{Diskuse výsledků environmentálních analýz}

Rýžování v povodí Černého potoka a jeho přítoků vstoupilo do krajiny, která nebyla narušena člověkem. Podobná situace je dokumentována na několika místech v Krušných horách (Kočár et al. 2018, 49-61; Tolksdorf et al. 2018), ale např́íklad na Českomoravské vrchovině na některých hornických lokalitách předcházela těžbě fáze zemědělské, nebo minimálně pastevecké kolonizace, dokumentované např́íklad na lokalitě Cvilínek (Hrubý et al. 2012; Kaiser et al. 2020). Pylové spektrum i spektrum rostlinných makrozbytků ukazuje převahu lesní vegetace na zkoumaných lokalitách. Lidské aktivity měly pravděpodobně jen krátké trvání, přesto samozřejmě lokálně způsobovaly rychlou změnu vegetace, ta však ne vždy vedla ke vzniku trvalého bezlesí. Doposud nedošlo $\mathrm{k}$ masivnímu a plošnému odlesnění okolní krajiny nebo zásadní změně druhového složení lesní vegetace. Údolní niva byla pokrytá převážně smrkem (Picea), to je důvodem jeho nadhodnocení v lokálním palynologickém a makrozbytkovém záznamu (Hájková et al. 2019; Kaiser et al. 2020) vůči okolní lesní vegetaci (Dudová et al. 2018), kde převažovaly jedle (Abies) a buk (Fagus). Středověké odlesnění vedoucí ke vzniku dnešní převážně lesů prosté krajiny je často líčeno jako rychlý frontální proces. Environmentální proxy data tuto představu poněkud modifikují. Podceňován je zejména proces regenerace lesní vegetace na stanovištích, kde po první vlně montánních aktivit nedošlo k záboru uvolněné půdy pro zemědělské účely (lokality Suchá Rudná a Nová Véska). Teprve v této fázi kolonizace, respektive regenerace lesa, dochází ke změně druhového složení zbylé lesní vegetace, kdy jsou jedlobukové lesy nahrazeny lesy s převahou smrku. Proces je to pozvolný a je doložen i v dalších horských krajinách stř̌ední Evropy, přičemž ne vždy souvisí s „umělým“ zalesňováním smrkem (Hrubý et al. 2014; Tolksdorf et al. 2020). Smrk totiž přednostně zmlazuje na místech narušených těžbou, kde není konkurence ostatních dřevin a bylin (Hammond-Pokorný 2020).

Na lokalitě Suchá Rudná byl omezeně doložen pouze pyl obilovin a některé luční či pastevní indikátory. Nelze předpokládat zemědělské zázemí v okolí této hornické lokality. Tím se výsledky liší např́iklad od hornických lokalit na Českomoravské vrchovině datovaných do stejného období a zkoumaných pomocí obdobných metod (Hrubý et al. 2014), u nichž je zemědělské zázemí 
doloženo jako současné s hornickou aktivitou. Nová Véska byla pravděpodobně zásobována ze vzdálenějšího okolí, podobně jako hornické sídliště v Krušných horách, kde je doložen import obilí z nížiny (Kočár et al. 2014, 124). V letech 2020 a 2021 byl realizován archeologický výzkum polohy jižně od kostela Neposkvrněného početí P. Marie ve Starém Městě (Brhelová-Zezula 2021), při němž byly zachyceny pozůstatky osídlení z průběhu 13. století a raného novověku. Lze tedy očekávat, že archeobotanické analýzy odebraných vzorků zeminy umožní sledovat transformaci zdejší montánní krajiny v region s převahou agrární činnosti.

\section{Závěr}

Rýžoviště v Nové Vésce nepatří v rámci jesenických horních revírů $\mathrm{k}$ největším ani k morfologicky nejvýraznějším - taková nalezneme například na horním toku Opavy mezi Novými Heřminovy a Vrbnem p. Pradědem nebo v okolí Zlatých Hor. Jeho význam ale spočívá v tom, že se nachází nejblíže Starému Městu jako výchozímu bodu exploatačních aktivit zaměřených na zlatonosné sedimenty a s nimi spojeného osídlovacího procesu. Montánní reliéf vzácně dochovaný v zalesněném prostoru údolní nivy Černého potoka na pomezí katastrů Nové Vésky a Staré Rudné umožňuje dobře pochopit dynamiku postupu těžby v průběhu 13. století a její dopad na reliéf a vegetaci zdejší podhorské krajiny. I když dále po proudu vznik intravilánů Nové Vésky a Starého Města v podstatě souvisle na sebe navazujících do značné míry setřel stopy exploatační činnosti, je pravděpodobné, že jádro lokačního Bruntálu, situované na vyšším nivním stupni Černého potoka někde v okolí kostela Neposkvrněného početí Panny Marie ve Starém Městě, na tato rýžoviště navazovalo, a bylo s nimi geneticky spojeno. Mimo to se ukázalo, že k rekonstrukci osídlovacího procesu lze také s úspěchem využít terénní archeologické relikty středověkého hornictví, které uchovávají paleoekologický záznam tehdejší vegetace a ukazují ve velkém detailu způsob tehdejší kolonizace. To částečně nahrazuje absenci archeologických artefaktů $\mathrm{v}$ těchto terénních situacích. Výsledky archeobotanických analýz dokládají prííchod prvních kolonizátorů do zcela nenarušené krajiny, kdy těžba proběhla současně s iniciálním odlesněním. Následný vývoj lokality ukazuje na regeneraci lesa v krajině po ukončení těžby a sporadické zemědělské aktivity v okolí. První hornické osídlení nebylo obklopeno zemědělským zázemím, zemědělství se rozvinulo pravděpodobně až po ukončení těžby a stabilizaci dodnes dochované sídelní struktury v době, kdy osídlovací proces byl již podchycen písemnými prameny.

Tato studie vznikla v rámci projektu Archeologie z nebe. Analýza a prezentace fondů dálkového průzkumu na Moravě a ve Slezsku, podpořeného Ministerstvem kultury ČR v Programu aplikovaného výzkumu a vývoje národní a kulturní identity (NAKI II), č. DG18P02OVV058.

\section{Prameny, literatura a elektronické zdroje}

CDB II: Codex diplomaticus et epistolaris regni Bohemiae II. (1198-1230). (Friedrich, G., ed.). Prague 1912.

CDS II: Codex diplomaticus nec non epistolaris Silesiae II. (1205-1220). (Maleczyński, K., ed.). Wrocław 1959.

BAKALA, J., 2002: Moravskoslezské pomezí v proměnách 13. věku. Výbor z článků a studií. Brno.

BRHELOVÁ, J.-ZEZULA, M., 2021: Staré Město, intravilán. Nálezová zpráva z archeologického výzkumu provedeného v rámci projektu Archeologie z nebe. Analýza a prezentace fondů dálkového průzkumu na Moravě a ve Slezsku, podpořeného Ministerstvem kultury ČR v Programu aplikovaného výzkumu a vývoje národní a kulturní identity (NAKI II), č. DG18P02OVV058. Uloženo v archivu odboru archeologie NPÚ, ÚOP v Ostravě.

BRONK RAMSEY, C., 2009: Bayesian analysis of radiocarbon dates, Radiocarbon 51, 337-360. https://doi.org/10.1017/S0033822200033865 
DERNER, K. et al., 2019: Derner, K.-Hrubý, P.-Malina, O.-Večeřa, J., Hornické revíry vrcholného středověku a raného novověku ve srovnávacím pohledu - Bergbaureviere des Hochmittelalters und der frühen Neuzeit in vergleichender Perspektive, AH 44, 925-947. https://doi.org/10.5817/AH2019-2-18

DUDOVÁ, L.-HÁJEK, M.-HÁJKOVÁ, P., 2010: The origin and vegetation development of the Rejvíz pine bog and the history of the surrounding landscape during the Holocene, Preslia 82, 223-246.

DUDOVÁ, L. et al., 2013: Dudová, L.-Hájková, P.-Buchtová, H.-Opravilová, V., Formation, succession and landscape history of Central-European summit raised bogs: A multiproxy study from the Hrubý Jeseník Mountains, The Holocene 23, 230-242. https://oi.org/10.1177/0959683612455540

DUDOVÁ, L. et al., 2014: Dudová, L.-Hájková, P.-Opravilová, V.-Hájek, M., Holocene history and environmental reconstruction of a Hercynian mire and surrounding mountain landscape based on multiple proxies, Quaternary Research 821, 107-120. https://doi.org/10.1016/j.yqres.2014.04.017

DUDOVÁ, L. et al., 2018: Dudová, L.-Hájek, M.-Petr, L.-Jankovská, V., Holocene vegetation history of the Jeseníky Mts: Deepening elevational contrast in pollen assemblages since late prehistory, Journal of Vegetation Science 29, No. 3, 371-381. https://doi.org/10.1111/jvs.12612

GOŠ, V.-KAREL, J., 2003: Počátky Rýmařova, nový pohled na předlokační osadu města - Anfange der Stadt Rýmařov (Römerstadt). Neue Erkenntnisse über die Vorlokationsbesiedlung, AH 28, $297-302$.

HÁJKOVÁ, P. et al., 2019: Hájková, P.-Jamrichová, E.-Wieznik, M.- Peterka, T.-Petr, L.-Singh, P.Mališ, F.-Fajmonová, Z.-Hájek, M., Spruce representation in zonal woodlands may be overestimated when using pollen spektra from peatlands, Review of Paleobotany and Palynology 271, 1-7. https://doi.org/10.1016/j.revpalbo.2019.104104

HAMMOND, M. E.-POKORNÝ, R., 2020: Effects of gap size on natural regeneration and micro-environmental soil conditions in European beech (Fagus sylvatica L.) and Norway spruce (Picea abies (L.) Karst) dominated mixed forest, Plant Soil Environment 66, 607-615. https://doi.org/10.17221/397/2020-PSE

HANUŠ, J.-FAJMON, L., 2021: Technická zpráva. Strojopis uložený v archivu odboru archeologie NPÚ, ÚOP v Ostravě.

HRUBÝ, P. et al., 2006: Hrubý, P.-Jaroš, Z.-Kočár, P.-Malý, K.-Mihályiová, J.-Militký, J.-Zimola, D., Stř̌edověká hornická aglomerace na Starých Horách u Jihlavy, PA XCVII, 171-264.

HRUBÝ, P. et al., 2012: Hrubý, P.-Hejhal, P.-Hoch, A.-Kočár, P.-Macháňová, L.-Malý, K.-Petr, L.Štelcl, J., Středověký úpravnický a hornický areál Cvilínek u Černova na Pelhřimovsku - Das mittelalterliche Aufbereitungs- und Bergbauareal Cvilínek bei Černov in der Gegend Pelhřimov, PA CIII, 339-418.

HRUBÝ, P. et al., 2014: Hrubý, P.-Hejhal, P.-Malý, K.-Kočár, P.-Petr, L., Centrální Českomoravská vrchovina na prahu vrcholného středověku: archeologie, geochemie a rozbory sedimentárních výplní niv. Opera Universitatis Masarykianae Brunensis, Facultas Philosophica 422. Brno.

JENÍK, J.-HAMPEL, R., 1991: Die Waldfreien Kammlagen des Altvatergebirges (Geschichteund Ökologie). Stuttgart.

JONES, M. K., 1991: Sampling in Palaeoethnobotany. In: Progress in Old World Palaeoethnobotany, 53-63. Rotterdam.

KAISER, K. et al., 2020: Kaiser, K.-Hrubý, P.-Tolksdorf, J. F.-Alper, G.-Herbing, C.-Kočár, P.-Petr, L.Schulz, L.-Heinrich, I., Cut and covered: Subfossil trees in buried soils reflect medieval forest composition and exploitation of the central European uplands, Geoarchaeology 35, 42-62. https://oi.org/10.1002/gea.21756

KEJŘ, J., 1998: Vznik městského zřízení v českých zemích. Praha.

KLÁPŠTĚ, J., 2005: Proměna českých zemí ve středověku. Praha.

KOČÁR, P. et al., 2014: Kočár, P.-Kočárová, R.-Petr, L.-Crkal, J.-Derner, K.-Lissek, P., Rostlinné zbytky z vrcholně středověkých hornických lokalit Krušných hor - Pflanzenreste aus den hochmittelalterlichen Bergbaustandorten im Erzgebirge. In: ArchaeoMontan 2014. Ergebnisse und Perspektiven. Výsledky a výhledy. Arbeits- und Forschungsberichte zur sächsischen Bodendenkmalpflege. Beiheft 29 (Smolnik, R., ed.), 119-135. Dresden.

KOČÁR, P.-PETR, L.-KOČÁROVÁ, R., 2018: Změny vegetace v hornickém revíru Přísečnice- Vegetationswandel im Bergrevier Preßnit. In: Archaeomontan 5, 2018. Středověké hornictví a hutnictví na Př́sečnicku ve středním Krušnohoří - Mittelalterlicher Bergbau und Hüttenwesen in der Region Preßnitz im mittleren Erzgebirge Veröffentlichungen des Landesamtes für Archäologie Sachsen, Band 68. (Derner, K., ed.), 47-78. Dresden. 
MALÍK, P.-VEČEŘA, J.-ZEZULA, M., 2017: Archeologický výzkum těžebního areálu v Suché Rudné. In: Těžba zlata na Bruntálsku. Montánní region pohledem interdisciplinárního výzkumu (Prix, D.-Večer̆a, J.-Zezula, M., edd.). Ostrava.

MOORE, P. D.-WEBB, J. A.-COLLINGSON, M. E., 1991: Pollenanalysis. Second edition. Oxford.

NALEPKA, D.-WALANUSZ, A., 2003: POLPAL - Program for counting pollen grains, diagram plotting and numericalanalysis, Acta Palaeobotanica - Suppl. 2, 659-661.

NEUHÄUSLOVÁ, Z. et al., 1998: Mapa potenciální přrirozené vegetace České republiky. Praha.

NOVÁK, J., 1990: Prospekce Jeseníků Au. Revize pozůstatků sekundárních ložisek Au. Nepublikovaná práce, ulož. v UNIGEO, s. p. Ostrava, závod Zlaté Hory.

NOVÁK, J.-KUBA, B., 1990: Povrchové dobývání zlatonosných sedimentů v Jeseníkách na Bruntálsku, Zkoumání výrobních objektů a technologií archeologickými metodami 6, 68-79.

NOVÁK, J.-PETR, L.-TREML, V., 2010: Late-Holocene human-induced changes to the extent of alpine areas in the East Sudetes, Central Europe, The Holocene 20, 895-905.

PRIX, D., 2017: Bruntálsko ve středověku. In: Těžba zlata na Bruntálsku. Montánní region pohledem interdisciplinárního výzkumu (Prix, D.-Večeřa, J.-Zezula, M., edd.). Ostrava.

REIMER, P. J. et al., 2020: Reimer, P. J.-Austin, W. E. N.-Bard, E.-Bayliss, A.-Blackwell, P. G.-Bronk Ramsey, C.-Butzin, M.-Cheng, H.-Edwards, R. L.-Friedrich, M.-Grootes, P. M.-Guilderson, T. P.-Hajdas, I.Heaton, T. J.-Hogg, A. G.-Hungen, K. A.-Kromers, B.-Manning, S. W.-Muscheler, R.-Palmer, J. G.-Pearson, C.-Van Der Plicht, J.-Reimer, R. W.-Rrichards, D. A.-Scott, E. M.-Southorn, J. R.-Turney, C. S. M.Wacker, L.-Adophi, F.-Büntgen, U.-Capano, M.-Fahrni, S. M.-Fogtmann-Schultz, A.-Friedrich, R.Köhler, P.-Kudsk, S.-Miyvake, F.-Olsen, J.-Reining, F.-Sakamoto, M.-Sookdeo, A.-Talmo, S., The IntCal20 Northern Hemisphere radiocarbon age calibration curve (0-55 CAL kBP), Radiocarbon 62, 725-757. https://doi.org/10.1017/RDC.2020.41

RYBNÍČEK, K.-RYBNÍČKOVÁ, E., 2004: Pollen analyses of sediments from the summit of the Praděd Range in the Hrubý Jeseník Mts (Eastern Sudetes), Preslia 76, 331-348.

SCHWEINGRUBER, F. H., 1978: Mikroskopische Holzanatomie. Kommissionsverlag Zürcher Zug.

STOLARCZYK, T., 2012: Těžba polymetalických rud v Dolním Slezsku od 13. do počátku 17. století, Acta rerum naturalium $12,61-78$.

- 2013: Der Bergbau in Niederschlesien in 13.-14. Jahrhundert - der archäologische Forschungsstand, Praehistorica XXXI, 655-678.

SZABÓ, P. et al., 2017: Szabó, P.-Kuneš, P.-Svobodová-Svitavská, H.-Švarcová, M. G.- Křižová, L.-Suchánková, S.-Mülerová, J.-Hédl, R., Using historical ecology to reassess the conservation status of coniferous forests in Central Europe, Conservation Biology 31, No. 1, 150-160. https://doi.org/10.1111/cobi.12763

TEJKAL, M., 2019: Nová Véska - Černý potok, digitální model terénu. Technická zpráva a mapové podklady. Nepublikovaná práce uložená v archivu odboru archeologie NPÚ, ÚOP v Ostravě.

TOLKSDORF, J. F. et al., 2018: Tolksdorf, J. F.-Petr, L.-Schubert, M.-Herbig, C.-Kaltofen, A.-Matson, S.Hemker, C., 2018: Palaeoenvironmental Reconstruction in the Mining Town of Freiberg (Lkr. Mittelsachsen) in Saxony, from the 12th Century onwards, Archäologisches Korrespondenzblatt: Urgeschichte, Römerzeit, Frühmittelalter, Verlag P. von Zabern 48, No. 2, 281-296.

TOLKSDORF, J. F. et al., 2020: Tolksdorf, J. F.-Kaiser, K.-Petr, L.-Herbig, C.-Kočár, P.-Heinrich, S.-Wilke, F. D. H.-Theuerkauf, M.-Fulling, A.-Schubert, M.-Schroder, F.-Křivánek, R.-Schulz, L.-Bonhage, A.Hemker, C., 2020: Past human impact in a mountain forest: geoarchaeology of a medieval glass production and charcoal hearth site in the Erzgebirge, Germany, Regional Environmental Change 27, No. 3, 1-20.

TOLKSDORF, J. F.-SCHUBERT, M. et al., 2019: Tolksdorf, J. F.-Schubert, M.-Schröder, F.-Petr, L.-Herbing, C.-Kočár, P.-Bertuch, M.-Hemker, S., Fortification, mining, and charcoal production: landscape history at the abandoned medieval settlement of Hohenwalde at the Faule Pfütze (Saxony, Eastern Ore Mountains), E\&G Quaternary Science Journal 67, 73-84. https://doi.org/10.5194/egqsj-67-73-2019

TOLKSDORF, J. F.-SCHÖDER, F. et al., 2019: Tolksdorf, J. F.-Schöder, F.-Petr, L.-Herbing, C.-Kaiser, K.- Kočár, P.- Fülling, A.-Heinrich, S.-Höni, H.-Hemker, C., Evidence for Bronze Age and Medieval tinplacermining in the Erzgebirgemountains, Saxony (Germany), Geoarchaeology 35, No. 2, $198-216$. 
TREML, V.-JANKOVSKÁ, V.-PETR, L., 2008: Holocene dynamics of the alpine timberline in the High Sudetes, Biologia 63, No. 1, 73-80.

VAN DER VEEN, M. M., 1984: Sampling for Seeds. In: Plants and Ancient Man. Balkema, 193-199. Rotterdam.

VEČEǨA, J., 2007: Analýza povrchových tvarů Andělskohorského rudního revíru, část Hláska-Vysoká. In: Stř́brná Jihlava 2007 - Suplementum 1. Archeologické výzkumy na Vysočině, 64-75. Jihlava - Brno.

- 2013: Kolonizační snahy Vladislava Jindřicha a Přemysla Otakara I. na severní Moravě, Archeologia technica 24 , č. 1, 8-13.

- 2017: Vývoj dolování. In: Těžba zlata na Bruntálsku. Montánní region pohledem interdisciplinárního výzkumu (Prix, D.-Večeřa, J.-Zezula, M., edd.). Ostrava.

VEČEǨA, J.-MALÍK, P.-ZEZULA, M., 2014: Suchá Rudná - záchranný archeologický výzkum a geologická charakteristika lokality, Acta rerum naturalium 16, 75-83.

WALDHAUSER, J., 1972: Tajemství Růženčiny zahrádky neodhaleno, Krkonoše 3, 12-13.

WIHODA, M., 2019: Vladislav Jindřich. Praha.

ZEZULA, M., 2017: Bruntálsko a Andělskohorský rudní revír pohledem archeologie. In: Těžba zlata na Bruntálsku. Montánní region pohledem interdisciplinárního výzkumu (Prix, D.-Večeřa, J.-Zezula, M., edd.). Ostrava.

ŽEMLIČKA, J., 2002: Počátky Čech královských 1198-1253. Proměna státu a společnosti. Praha.

\section{Zusammenfassung}

\section{Archäologische Grabung an der Goldseife in Nová Véska (Ortsteil der Gemeinde Staré Město, Bezirk Bruntál)}

Das vor dem Jahr 1213 durch Lokation erschlossene Bruntál ist die älteste institutionelle Stadt in den böhmischen Ländern. Man nimmt an, dass die Stadt in der ersten Hälfte des 13. Jahrhunderts noch keine feste urbane Struktur hatte und das Magdeburger Stadtrecht Siedlungen sicherte, deren Einwohner an der Goldgewinnung aus Sedimenten der dortigen mit Gold angereicherten Wasserläufe beteiligt waren (Abb. 1 und 3). An archäologischen Belegen für die älteste mittelalterliche Besiedelung der Region Bruntál (Freudental) gibt es bislang nur wenige, und die meisten von ihnen stammen aus der Umgebung der Kirche zur Unbefleckten Empfängnis der Jungfrau Maria in Staré Město (Altstadt). Die größte Bedeutung bezüglich den Erkenntnissen über die Bergbautätigkeit in jenem Zeitraum hat die archäologische Grabung im Abbau- und Verarbeitungsareal in Suchá Rudná (Dürrseifen), das dendrochronologisch an das Ende der dreißiger Jahre des 13. Jahrhunderts datiert wird.

Die in den Jahren 2019 bis 2020 in dem im Jahr 1405 erstmals in schriftlichen Quellen erwähnten Dorf Nová Véska (Neudörfel) durchgeführte archäologische Grabung konzentrierte sich auf eine selten erhalten gebliebene Goldseife im waldbedeckten Gelände in der Inundation des Baches Černý potok (Schwarzer Bach) im Westteil des Gemeindekastasters. In der ersten Phase wurde ein Teil der Goldseife mittels terrestrischem Laserscanning vermessen (Abb. 5-7), an Stellen mit mutmaßlichen Aquifersedimenten wurden zwei archäologische Sondierschnitte gelegt. Aus den untersuchten Schichten wurden Proben für eine archäobotanische Analyse und eine Radiokarbondatierung entnommen. Im Rahmen einer Umweltuntersuchung wurde auch ein Profil der Auensedimente in ihrer nördlichen Nachbarschaft, d.h. bereits im Kataster der Nachbargemeinde Stará Rudná entnommen. Anschließend wurde das Gelände der Goldseife mit einem Airborne-Laserscanner vermessen. Die Visualisierung der gewonnenen Daten ermöglichte ihre detaillierte Beschreibung und eine Analyse der Geländeformen (Abb. 4).

Aus Sicht der Genese kann die Goldseife in mehrere Teile unterteilt werden (Abb. 5, Flächen 1-5). Die Flächen 1 und 5 werden durch Abraumhalden charakterisiert, die entlang von Wasserkanälen aufgeschüttet sind, die am Fuß der gegenüberliegenden Abbauwand verlaufen, 
Fläche 4 könnte eine Tagebaustätte mit einem Kanal und Wasserbecken sein, Fläche 2 ist flaches Gelände, das nicht zuverlässig interpretiert werden kann, und Fläche 3 wird offenbar durch Flutwasser modelliert. Die Analyse des in den archäologisch untersuchten Halden und Geländedepressionen füllenden Schichten abgelagerten Materials (Sondierschnitte S 18 und S 19, Abb. 8-10) zeigt die Art und Weise der Verarbeitung der ausgewaschenen Sedimente und den Entstehungsmechanismus des dortigen Montanreliefs auf. Der eigentliche Gegenstand des Abbaus waren alluviale Sedimente, die Gold enthielten, das in der verwitterten Felssohle eingeschlossen war. Das auf den Halden abgelagerte Material besteht aus Tonsteinabraum, ausgeschwemmten Sedimenten, Ablagerungen, die beim Entschlammen des Seifenmaterials anfallen, aus Auenlehm und der Humusdeckschicht.

Die aus den archäologisch untersuchten Sondierschnitten entnommenen Pollenprofile spiegeln zusammen mit dem Profil in der nördlich von der Goldseife gelegenen Aue (Abb. 11) unterschiedliche Entstehungsbedinungen der dokumentierten Schichtenfolge wider. Im unteren Teil der Profile kann eine palynologische Aufzeichnung der ursprünglichen Umgebung und der Vegetation der Bachaue identifiziert werden, in der der Goldabbau stattfand, und zwar mit einer Dominanz von Fichten, eventuell Tannen, ohne Belege für eine lokale landwirtschaftliche Produktion. Nach Beendigung des Abbaus ist in der Pollenaufzeichnung eine teilweise Regenerierung des Waldes zu sehen, die laut Radiokarbondatierung in das 14. Jahrhundert fällt (Abb. 13), gefolgt von einem allmählichen Rückgang der Pollen von Gehölzen infolge einer weiteren Entwaldung, einer Zunahme von Gräserpollen und dem Auftreten deutlicher Kurven von Getreide- und Hanfpollen, einschließlich Ruderal- und Weideunkraut als Spiegelbild der mittelalterlichen Kulturlandschaft.

Die vorliegende Studie entstand im Rahmen des Projektes Archäologie vom Himmel. Analyse und Präsentation der Fernuntersuchungsbestände in Mähren und Schlesien, das vom Ministerium für Kultur der Tschechischen Republik im Programm Nr. DG18P02OVV058 angewandte Erforschung und Entwicklung der nationalen und kulturellen Identität (NAKI II) gefördert wird.

Mgr. Michal Zezula, Ph.D., Národní památkový ústav, územní odborné pracoviště v Ostravě, Odboje 1, 70200 Ostrava - Moravská Ostrava, Česká republika, zezula.michal@npu.cz

Bc. Jana Brhelová, Národní památkový ústav, územní odborné pracoviště v Ostravě, Odboje 1, 70200 Ostrava - Moravská Ostrava, Česká republika, janabrhelova@seznam.cz

Mgr. Petr Kočár, Archeologický ústav AV ČR, Praha, v. v. i., Letenská 4, 11801 Praha, Česká republika, kocar@arup.cas.cz

Mgr. Libor Petr, Ph.D., Ústav botaniky a zoologie Př́rodovědecké fakulty Masarykovy univerzity, Kotlářská 2, 61137 Brno, Česká republika, petr.libor@gmail.com

RNDr. Josef Večeřa, Česká geologická služba, Erbenova 348, 79001 Jeseník, Česká republika, josef.vecera@geology.cz 
